\title{
The aging venous system: from varicosities to vascular cognitive impairment
}

\author{
Andrea Ágnes Molnár · György László Nádasy · Gabriella Dörnyei · \\ Bernadett Bettina Patai · Jordan Delfavero · Gábor Áron Fülöp • \\ Angelia C. Kirkpatrick · Zoltán Ungvári • Béla Merkely
}

Received: 20 July 2021 / Accepted: 12 October 2021 / Published online: 11 November 2021

(C) The Author(s) 2021

\begin{abstract}
Aging-induced pathological alterations of the circulatory system play a critical role in morbidity and mortality of older adults. While the importance of cellular and molecular mechanisms of arterial aging for increased cardiovascular risk in older adults is increasingly appreciated, aging processes of veins are much less studied and understood than those of arteries. In this review, age-related cellular and morphological alterations in the venous system are presented.
\end{abstract}

A. Á. Molnár $(\square)$ · G. Á. Fülöp · B. Merkely

Heart and Vascular Center, Semmelweis University, Városmajor Street 68, 1121 Budapest, Hungary

e-mail: molnarandreaagnes@gmail.com

\section{G. L. Nádasy}

Department of Physiology, Semmelweis University, Budapest, Hungary

G. Dörnyei

Department of Morphology and Physiology, Health Sciences Faculty, Semmelweis University, Budapest, Hungary

B. B. Patai

Department of Traumatology, Military Hospital, Budapest, Hungary

J. Delfavero $\cdot$ Z. Ungvári

Vascular Cognitive Impairment and Neurodegeneration Program, Center for Geroscience and Healthy Brain Aging/Reynolds Oklahoma Center On Aging, Department of Biochemistry and Molecular Biology, University of Oklahoma Health Sciences Center, Oklahoma City, OK, USA
Similarities and dissimilarities between arterial and venous aging are highlighted, and shared molecular mechanisms of arterial and venous aging are considered. The pathogenesis of venous diseases affecting older adults, including varicose veins, chronic venous insufficiency, and deep vein thrombosis, is discussed, and the potential contribution of venous pathologies to the onset of vascular cognitive impairment and neurodegenerative diseases is emphasized. It is our
A. C. Kirkpatrick
Department of Medicine, University of Oklahoma Health Sciences Center, Oklahoma City, OK, USA

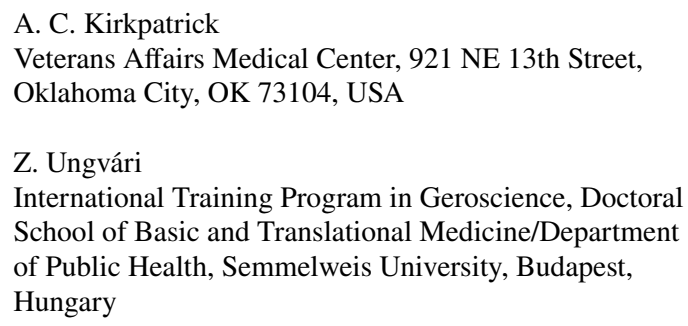


hope that a greater appreciation of the cellular and molecular processes of vascular aging will stimulate further investigation into strategies aimed at preventing or retarding age-related venous pathologies.

Keywords Veins - Aging - Venous insufficiency . Deep vein thrombosis - Varicose veins . GeroScience - Vascular cognitive impairment · Ageing

\section{Introduction}

Diseases that affect the circulatory system, including cardiovascular and cerebrovascular diseases, are the most common cause of death among older people in the developed countries [1]. The extent of human suffering, death, and economic damage caused by venous diseases in older adults is not far from that caused by arterial diseases [2-8]. The prevalence of several diseases of the arterial system exponentially increases with advancing age $[9,10]$. Although several important venous diseases frequently appear at younger ages, their accumulation and progression with advanced age are also typical. Age is now accepted as an important independent risk factor of venous diseases [3-8, 11, 12]. Yet, the mechanisms and consequences of aging in veins are less extensively studied.

Aging of the arterial system and its pathological consequences have recently been reviewed in detail $[9,10,13]$. Cellular components of the venous wall are identical or close to those of the arteries and arterioles. It is assumed that many of the cellular and molecular aging processes that contribute to arterial aging impact also venous aging; however, there are important dissimilarities between aging of the venous and arterial systems and their pathological manifestations. This review discusses the shared processes of vascular aging and their putative contribution to age-related venous pathologies (Fig. 1) and highlights important differences between arterial and venous aging.

\section{Aging of veins and arteries: similarities and dissimilarities}

There are important differences between the functional anatomy of veins and arteries which contribute to their differential sensitivity to agerelated deterioration. Aging promotes atherosclerosis in the arteries [14, 15]. Although veins are exposed to the same circulating factors, they are free from atherosclerotic plaque development. This is primarily due to the markedly different hemodynamic environment in the arterial and venous circulations. Active and passive force-bearing elements of the venous wall are not stretched by the unceasing high wall stress caused by the high diastolic value of arterial pressure and its aggressive pulsatile alterations. Although similar age-related phenotypic alterations occur in the endothelial and smooth muscle cells (including a heightened state of inflammation), the hemodynamic environment and the altered response to injury of the vascular cells determine specific manifestations of vascular pathologies in the aged arteries and veins. Further, the venous endothelium is not subjected to the highest oxygen tension in the body like its arterial counterpart. Also, venous wall shear stress is much less than in the arteries due to the slower blood flow velocity. Yet, high wall stress can develop in the venous system. For example, the lower extremity of humans, to which the genetic adaptation still does not seem to be fully adequate, is a predilection site for disease [16]. The slower blood flow increases the danger of thrombotic processes, by elevating the probability of platelet and white blood cell attachment and also erythrocyte retention [17]. The blood reservoir function of veins requires extensive smooth muscle contraction to ensure appropriate vessel volume. The vein valves, which are tiny, sensitive anatomical structures, are frequently subjected to pathological processes $[18$, 19].

Endothelial cells of arteries are in direct contact with oxygenized blood, while high pressures of arterial blood extending into the inner layer of the artery wall exclude establishment of any microcirculation here. There is a much different situation in the venous wall. Exhausted blood is in contact with the inner layers but vasa vasorum microcirculation is possible in the wall.

The time course of venous pathologies is different from that of arterial diseases: many serious, advanced cases of venous disease accumulate at relative early age. Notwithstanding, there is a significant increase 
1. Intima, endothelial cells

- Thickening, subintimal connective tissue accumulation

- Increased permeability, diffusion of citokines, inflammation factors

- Adhesion proteins $\uparrow$ Adhesion and migration of white cells

- Transformation of endothelial cells into senescent secretory type by TGFbeta

- Endothelial cell expression $\uparrow$ Chemokines, IL1alfa, IL6, IL8, MCP-1; Growth

factors, VEGF, TGFbeta; Proteases, MMP-1, MMP-3, PAI-1; iNOS; fibronectin.

- Number of apoptotic cells $\uparrow$

-Altered surface glycoseaminoglycans, endothelin $\uparrow$, TXA2 $\uparrow$, platelet

adhesion $\uparrow$, thrombus formation $\uparrow$

- Endothelial cell degeneration

2.Smooth muscle

- Decreased cellularity, large polygonated cells, increased number of aged cell count, reduced cell division activity

- Increased expressions for laminin; adhesion proteins ICAM-1, VCAM-1; SM-MHC calponin; metalloproteinase inhibitors TIMP-2, TIMP-3.

- Decreased expressions of CK-8 and MMP-2.

- Increased number of apoptotic cells

- Atrophic and hypertrophic areas alternatively changing

- Reduced contractility

3. Connective tissue

- Fibrosis, driven by TGFbeta

- Decreased rate of exchange and renewal

- Increased expression of Iaminin, ICAM-1 and VCAM-1

- Altered balance of MMPs and TIMPS

- Fragmentation of elastica

- Decrease of elastin, reduced expression of tropoelastin and lysyl oxidase

- Fibrillin component of elastica fully missing at places

- Uncoupling of smooth muscle cell elastin receptor, increased expression of elastase

- Increased rigidity of the wall

4. Valves

- Valvular crypts will be shallower

- Thickening of the cusps

- Accumulation of disordered collagen, increasing rigidity

- Elastica appears at the cusps' base

- Blood stasis in sinuses promotes coagulation

- Blood stasis induced alterations in anti- and procoagulant protein expression

- Increased time of reverse flow, impaired valvular competence

5. Biomechanics and hemodinamics

- Increased rigidity of the wall, reduced compliance

- Irregular shape of lumen, wall thickness

- Reduced activity of postjunctional alpha2 adrenergic receptors

- Weakening of sympatehetic venoconstrictor reflexes

- Proneness for orthostatic hypotension (Exsiccosis, hemorrhage, heat exposition)

- Sedentary life style (Stasis, thrombosis)

- Valvular incompetence

- Increased venous pressure

- Flow disturbances: stasis, reverse flow, increased flow in collaterals,

in veins with deformed shape of lumen

Fig. 1 Aging processes identified in veins and their connections to venous pathology. For detailed description and references, see the corresponding chapters. Abbreviations: CK-8, Cytokeratin-8; FVIII, FIX, clot factors VIII and IX; ICAM-1, Intercellular adhesion molecule-1; iNOS, inducible nitrogen monoxide synthase; IL1 $\alpha$, IL6, IL8, interleukins 1alfa, 6, and 8; MCP-1, Monocyte chemotactic protein; MMP-1, MMP-2,

of venous pathologies with age $[3,4,6,7,12,20]$ induced by both the accumulation of age-dependent pathologic processes and by the increased sensitivity to inflammatory and thrombotic processes of the aged venous wall [21].
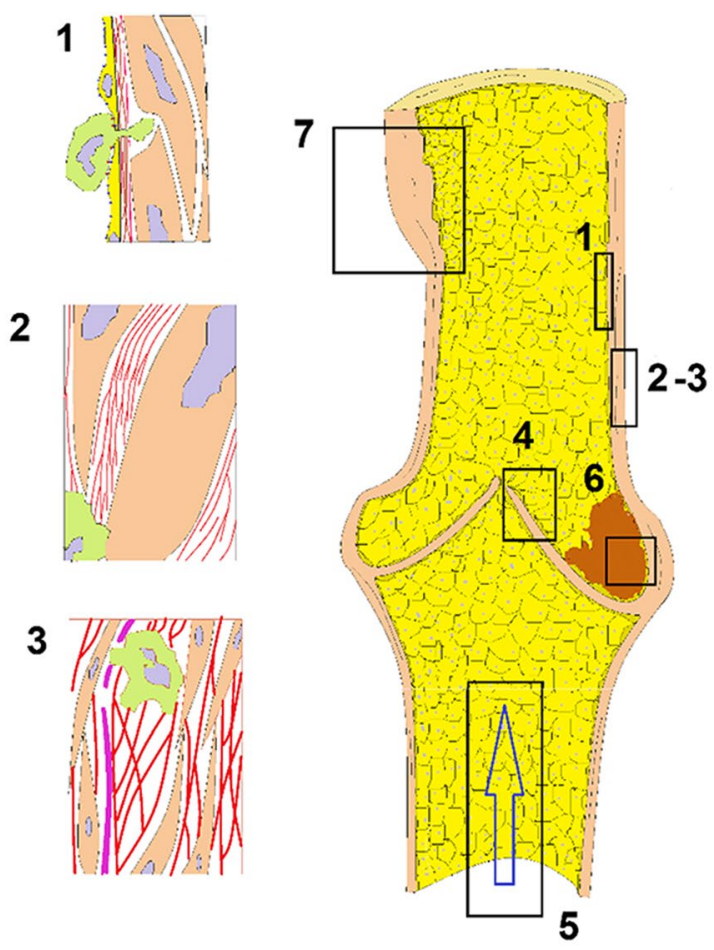

\author{
6. Thrombosis \\ - Surface proteoglycane alterations on venous endothelial cells \\ - Increased P-selectine expression of endothelial cells and platelets \\ - Prothrombin time $\uparrow$, platelet count $\uparrow$, fibrinogen $\uparrow$, FVIII $\uparrow$, FIX $\uparrow$, vWF $\uparrow$ \\ - PAl-1 from adipose tissue \\ - Sedentary life style \\ - Increased incidence of deep vein thrombosis and pulmonary embolism \\ - Repeated thrombotic events in case of minor genetic thrombophilic variabilities \\ - In the postthrombotic syndrome more extensive vein wall remodeling and repeated \\ thromboses \\ 7. Irregularities of wall thickness and lumen shape \\ - Elderly veins have thickened, typically unevenly thickened walls \\ - Local morphlogical dilations at sites of inhomogenous wall damage, TGFbeta, PDGF \\ and citokine production \\ - Incidence, prevalence and severity of chronic venous disease increase
}

MMP-3, Matrix metalloproteinases 1, 2, and 3; PAI-1; PDGF, platelet-derived growth factor; SM-MHC, Smooth muscle heavy chain; TIMP-2, TIMP-3, tissue inhibitor of matrix metalloproteinase 2 and 3; TxA2, thromboxane A2; VCAM-1, Vascular adhesion molecule-1; vWF, von Willebrand factor; TGFbeta, Transforming growth factor beta; VEGF, vascular endothelial growth factor

\section{Age-related cellular and morphological alterations in the venous system}

Endothelial aging

Among the cell types present in the vascular wall, endothelial cells are especially sensitive to the 
deleterious effects of aging [22-32]. There is increasing evidence that aging-induced phenotypic and functional alterations of endothelial cells contribute to the genesis of age-related venous pathologies, similar to the arterial system (Fig. 1). Endothelial dilation is depressed in aged veins [33], similar to aged arteries and arterioles [9, 23, 30, 34, 35]. Histologically endothelial cells in varicose saphenous vein specimens derived from older adults show progressive degeneration, and ultimately will be lost, exposing the basement membrane for platelets and clot factors and the medial layers for inflammatory protein permeation and migration of white cells [36]. The increased permeability of the endothelial layer in aged vessels promotes the entry of circulating inflammatory mediators (e.g., cytokines, factors that promote sterile inflammation) into the deeper layers of the vascular wall. With aging, vascular endothelial cells acquire a pro-inflammatory phenotype, which likely contributes to the development of venous diseases [37]. Varicose veins are characterized by up-regulation of iNOS [38], which is likely to promote the formation of peroxynitrite. Peroxynitrite is known to play multifaceted roles in vascular pathologies associated with aging, including activation of PARP-1 and promotion of mitochondrial dysfunction [39]. Also, an increasing ratio of aged endothelial cells undergo cellular senescence and exhibit a highly inflammatory senescent associated secretory phenotype (SASP). This phenotype is characterized by elevated expression and secretion of soluble signaling factors such as chemokines: IL8, MCP-1; interleukins, IL1 $\alpha$, IL6; growth factors: VEGF, TGF $\beta$; proteases: MMP-1, MMP-3, MMP-10, PAI-1; further endothelial NOsynthase; and matrix components (fibronectin) [21]. Age-related alterations of adhesion proteins and glycosaminoglycans on the surface of endothelial cells promote platelet adhesion and thrombus formation, as well as adhesion and transmigration of leukocytes [21]. Increased presence of white blood cells in the aged vascular wall also contribute to an inflammatory microenvironment in aged veins [21]. Aged endothelial cells exhibit impaired resilience to oxidative stressors and are more sensitive to apoptosis induction. Accordingly, the number of apoptotic endothelial cells increases in veins of older individuals [40]. In the human saphenous vein, there is an intimal thickening with advanced age [41]. Molecular alterations of endothelial cells will be discussed in detail below.

\section{Smooth muscle aging}

The aged venous media is scant of cellular components, smooth muscle cells are large, and cells obtained from aged donors are morphologically different from younger specimens when cultured [42]. Aged smooth muscle cells have a polygonate shape, and are frequently multinuclear. Their division activity ceases early, after about 10 passages [42]. In venous smooth muscle cell, sensitivity to growth factors substantially decreases with age [42]. The expression of laminin and of the adhesion proteins ICAM-1 and VCAM-1 increases with age [43]. In otherwise healthy saphenous vein graft samples, a positive correlation between age and the expressions of SM-MHC (Smooth Muscle Myosin Heavy Chain), calponin, TIMP-2 and TIMP-3 (Tissue Inhibitor of MetalloProteinase 2 and 3), and a negative correlation with CK-8 (Cytokeratin-8) and MMP-2 (matrix metalloproteinase-2) were found [44] demonstrating that a massive rearrangement of protein expression accompanies the aging process. There is a biologically significant phenotypic overlap with vascular smooth muscle cells isolated from pathologic varicose vein samples, in which expression of Bcl-2 (an apoptosis controlling protein, located at the outer mitochondrial membrane), MMP-1, MMP-2, TIMP-1, and TIMP-2 is dysregulated and proliferation, adhesion, and migration capacities are altered [45]. The number of apoptotic smooth muscle cells increases in the aged venous system as well as in the prevaricose-varicose venous wall [46-50]. In the affected venous networks, hypertrophic and atrophic areas are alternating giving a foundation for massive morphological deformations observed later in life [40, 47, 51].

\section{Connective tissue aging}

Connective tissue alterations in the aged, sclerotic, and varicose vessels were historically the first to be recognized. Decreased cellularity, elastic tissue damage, and collagen accumulation are important components of both aging and varicose 
transformation of the venous wall [19, 52, 53]. Similar to other tissues, TGF $\beta$ appears to govern the pro-fibrotic phenotypic changes both in the aged veins and in the varicose vein wall $[11,54]$. Turnover of connective tissue in the venous wall decreases with advancing age and with it the structure of elastic membranes and collagen bundles is altered. There is a higher level of MMP activity in aged veins, which contribute to the remodeling of the extracellular matrix. MMP activity is controlled by TIMP-s. In normal vascular tissue, there is a homeostatic balance between MMPs and TIMPs which is disturbed in pathological conditions, promoting the development of venous diseases, such as varicosities [54]. Fragmentation of the elastic membranes and disturbed contact of elastic fibers with smooth muscle cells are important factors in the mechanical weakness and morphological deformation of varicose venous segments [55-58]. Accordingly, enhanced elastase activity was noted in varicose saphenous vein specimens from elderly subjects [59]. In older patients, a general reduction in elastin content is evident in the venous wall [59]. This reduction is correlated with a lack of fibrillin-1 in some areas and with a disorganized pattern of cells expressing tropoelastin and fibrillin-1. A decline in elastin content is causally linked to the deformed morphology of varicose veins. These dilated, elastin-poor segments are alternating with nondilated segments with normal elastin and collagen content. Reduced expressions of the elastin precursor tropoelastin and of lysyl oxidase, the enzyme responsible for the cross-linking of mature elastic fibers was also demonstrated in older people [60]. One theory largely attributes the vascular aging process to the uncoupling of the smooth muscle elastin receptor which results in elevated elastase release [61]. These connective tissue rearrangements are accompanied by increased rigidity and reduced contractility of the wall with substantial hemodynamic consequences [18]. Expression of laminin and adhesion molecules increases in aging and likely contributes to the genesis of varicosities [43]. Diseased veins have marked alterations in the expression of extracellular matrix proteins and regulatory factors: while collagen I chain alpha 1 and alpha 2 and laminin beta-1, beta-2, and gamma-1 are upregulated, small leucine rich proteoglycans that control collagen fiber assembly are reduced in varicose veins [54].

Age-related changes in biomechanics and hemodynamics in veins

The age-related cellular and molecular alterations described above induce substantial alterations in the geometry and biomechanics of the vein wall, and consequent functional changes [62]. The venous wall is rigid at higher physiological pressures, while it is distensible at lower pressures. Venous wall thickening and increased collagen-to-elastin ratio reduces lower limb venous distensibility in the supine position by $78 \%$ in elderly population [63]. Furthermore, aging reduces calf venous compliance by up to $40-45 \%$ as the efficiency of the calf muscle pump decreases in resting venous capacity increases in older adults [63-65]. Distensibility of the upper limb venous system also decreases by $38 \%$ with aging [63]. In aging, the distensibility of inner jugular vein decreases by $68 \%$ in supine body position but increases by $106 \%$ in erect body position $[63,66]$. The maximum capacity of the internal jugular vein increases with aging and is more pronounced on the right side and in males [63]. In contrast, distensibility of axillary veins does not change significantly with age, which can be explained by their intramuscular location [63]. Age-related changes in venous distensibility and compliance can be attenuated by regular physical exercise [67].

The mechanisms responsible for orthostatic tolerance in humans affect mostly the venous system, which represents one of the major evolutionary challenges for our species. Beyond adaptation to the erect body position, veins control adaptation to altered blood volume. Local myogenic and humoral mechanisms as well as systemic hormonal and nervous system influence venous biomechanics [68]. Long-term gravitational adaptation leads to altered venous wall geometry, contractility, and innervation density as well as altered venous network [16, 68]. There is evidence that regulation of the aforementioned venous functions is affected by aging [63]. In saphenous veins of older adults, a reduced activity of postjunctional alpha2 adrenoreceptors was observed, which may adversely affect venoconstrictor reflexes [69]. Functional deterioration of venous adaptations 
substantially contributes to the proneness of elderly people for orthostatic hypotension, collapse of the circulation in exsiccosis, hemorrhage, and heat exposition. Of note, decreased sympathetic reflexes may be partially compensated for by the decreased compliance [70-73].

Age-related alterations in venous valves

The essential role of deep vein valves in the development of the varicosity disease has been recognized by Moore [74]. Venous valves are bicuspid and are positioned in a valve sinus, which is a local widening of the venous wall. The area between a valve leaflet and the vessel wall is called the valve pocket $[75,76]$. The two cusps are thicker at their attachment to the venous wall (termed the limbus). Microscopically, the luminalis zone is the part of the cusp close to the lumen and facing the circulating blood stream and consists one layer of endothelial cells [77]. Beneath this layer, there is a moderately thick, wavy elastic lamella, the continuation of the internal elastic lamella of the intima. The parietalis zone is the part of the cusp facing the vein wall of the sinus, and is lined by one layer of endothelial cells. The crypts lined by endothelium face the sinus with their bases and usually are found in irregular intervals. The parietalis zone consists of loosely arranged collagen fibers and connective tissue cells that is gradually replaced by a thick dense collagen starting after the age of 30 [77]. Aging crypts of the parietalis zone tend to become shallower and the thickness of the elastic lamellae increases slightly. From the sixth decade, the elastica itself becomes thicker in the aged and the fatty tissue extends from the adventitia into the media of the vein wall. Distal to the valve, there is a proliferation of subintimal connective tissue and elastic fibers with aging (termed endophlebohypertrophy) [77]. Overall, the venous valve becomes thickened and less flexible with increasing age resulting in blood flow disturbance, thus enhancing blood stasis in the valve sinus and increasing time of reverse flow after valve closure [77, 78]. Venous hypertension is a key factor in valvular remodeling [79]. The age-related thickening of venous valves is a result of alterations in valve cusp structure including increased collagen deposition [80, 81]. These structural changes lead to functional changes including diminished elasticity. Due to age-related blood stasis, there is increased risk for thrombosis. In patients with chronic venous disease, about $25 \%$ of valvular incompetence can be explained as a result of previous deep vein thrombosis [82]. The thrombus itself can mechanically damage the valve resulting in reflux of venous blood. Thicker and less flexible damaged valves in older adults are associated with deep vein thrombosis [83].

Usually, the inferior vena cava is without a valve. In about $70 \%$ of limbs, there is one valve in the common femoral vein the saphenofemoral junction that protects the saphenous axis against increases in intraabdominal venous pressure [76, 84]. The femoral vein exhibits approximately 3 valves, the popliteal veins 1 to 3. Many more valves are present in the deep venous system in the lower extremity: 8 to 19 valves are located in each of the posterior tibial veins and 8 to 11 valves in both the anterior tibial and peroneal veins $[75,85,86]$. The number of valves in perforating veins ranges between 1 and 5; however, avalvular perforating veins are mainly located in the foot, hand, and forearm [75]. Approximately 7 valves are located along the entire length of the great saphenous vein [87]. The number of valves in varicose saphenous veins is significantly lower compared to nonvaricose ones [88]. The number of valves in Africans is higher comparing to whites that may account for the high prevalence $(10-18 \%)$ of varicose veins in whites and the low prevalence (1-2\%) of the condition in Africans [85].

\section{Venous thrombosis}

In older adults, thrombotic risk is significantly increased [89] resulting in $1 \%$ per year incidence of venous thrombosis [90]. Deep vein thrombosis of the lower extremity is the most common form of thrombosis. Additionally, venous thrombosis can also occur in the superficial veins of the leg and also in other veins, such as veins of the upper extremity, liver, cerebral sinus, and retinal and mesenteric veins. The Worcester Deep Vein Thrombosis Study demonstrated that the incidence of both deep vein thrombosis and pulmonary embolism increases exponentially with age [91]. The mechanisms contributing to these age-related changes are multifaceted.

In aging, the endothelial cells exhibit pro-thrombogenic phenotypic changes [21] and the morphology of the venous wall is altered, forming recesses 
with low flow where activated clot factors and platelets can accumulate. Platelets and endothelial cells in older adults overexpress P-selectin, an inflammatory adhesion protein, contributing to a procoagulant state [92]. Aging may also be associated with shortened prothrombin time; increased plasma levels of FVII, FVIII, and vWF; and increased platelet counts [81] Increases in fibrinogen, factors VIII and IX, and other coagulation proteins, without a proportional increase in anticoagulant factors, likely contribute to the increased thrombosis risk [90].

Currently, over $35 \%$ of individuals aged 65 and older are obese (over 55\% of Black women) and if the current trend continues, nearly half of the elderly population in the USA will be obese by 2030 [93, 94]. Obesity in older adults may heighten thrombotic risks as the adipose tissue is an important source of factors regulating thrombus formation including inflammatory cytokines and plasminogen activator inhibitor-1 (PAI-1) [95].

Older adults frequently have a sedentary life style [96], which exacerbates the risk of venous thrombosis. The venous compliance in the calf decreases as the muscular tone of the calf decreases with age. As a result, the function of the aged venous valves often become impaired leading to higher thrombotic risk [97, 98]. The number of vascular risk factors and prevalence of chronic diseases are higher in the elderly population, which also contributes to higher thrombosis risk [98]. Additionally, abnormalities of the coagulation system, either genetic or acquired, exacerbate thrombotic risk. Acquired hypercoagulable states (e.g., associated with cancer) are more common in older adults. Inherited thrombophilia is caused by a variety of genetic abnormalities in anticoagulant factors such as antithrombin (AT), protein $\mathrm{C}$ (PC), and protein S (PS), or coagulation factors such as prothrombin and factor V. Genetic abnormalities in anticoagulant factors (such as deficiencies of antithrombin, protein $\mathrm{C}$ and protein $\mathrm{S}$ ) are found in $<1 \%$ of the population and often present with unusual clinical episodes and localization of venous thrombosis. In a large multicenter cohort study of familial thrombophilia (European Prospective Cohort on Thrombophilia, EPCOT), the annual rate of venous thrombosis was 8 per 1000 without a clear age effect [99]. However, the incidence of venous thrombosis in patients aged 45 years and older is higher (1-2\% per year) in retrospective family studies [100, 101]. Genetic abnormalities in procoagulant factors (e.g., Factor V Leiden, leading to APC-resistance and prothrombin G20210A leading to elevated levels of prothrombin) are common variants with an overall incidence of carriers of $2-5 \%$ among Caucasians and they are found in 6-20\% of patients with deep vein thrombosis [102-106]. The LITE (Longitudinal Investigation of Thromboembolism Etiology) study investigated the absolute risk of thrombosis for carriers of FV Leiden of different ages [107]. In subjects older than 45 years of age, FV Leiden led to a 4.6-fold increased risk of venous thrombosis (vs. noncarriers) [108]. Elevated levels of procoagulant factors (i.e., prothrombin (FII), FVIII, FIX, and FXI) are associated with the risk of thrombosis [109-111]. Regarding environmental factors, surgery, major trauma, immobilization, pregnancy, postpartum period, long-distance travel, and cancer are the main risk factors for deep vein thrombosis [112-115]. Hypercoagulability in patients with malignancy was described first by Armand Trousseau in 1865 [116]. Cancer may induce venous stasis, endothelial injury, and an imbalance of pro- and anti-thrombotic factors leading to a hypercoaguable state [115]. Immobilization and prolonged travel increases the risk of thrombosis 2- to threefold in older adults [114]. The RIETE (Registro Informatizado Enfermedad TromboEmbolica) registry is a large prospective multinational ongoing registry, designed to collect data of venous thromboembolism presentation, management, and outcomes from multiple centers in 24 countries [117]. In the RIETE registry of patients aged over 80 with venous thrombosis, it was found that they had been immobilized for more than 4 days and had chronic obstructive lung disease and heart failure [97].

The most serious complication of venous thrombosis is pulmonary embolization and paradoxical embolism leading to ischemic stroke. Paradoxical embolism resulting in ischemic stroke can occur in the case of a patent foramen ovale, present in about $20 \%$ of the population. When the right atrial pressure transiently exceeds the left atrial pressure, even small venous emboli can transmit the canal of patent foramen ovale. Post-thrombotic syndrome develops in approximately $25-60 \%$ of patients with acute lower extremity deep venous thrombosis depending on severity, chronicity, anatomic level of involvement, and efficacy of 
anticoagulation [118]. The most prominent clinical signs of post-thrombotic syndrome are leg swelling, pain, and skin alterations, and even skin ulceration.

Residual thrombus damages venous valves and obstructs outflow, the main etiologic factors for ambulatory venous hypertension, which has been shown to be significantly associated with an increased risk of post-thrombotic syndrome. The main pathomechanism leading to post-thrombotic syndrome is aseptic inflammation triggered by thrombus formation, which results in venous wall fibrotic remodeling. Additionally, thrombus formation via direct mechanical venous valve damage exacerbates venous valve incompetence, contributing to the development of post-thrombotic syndrome. The relationship between venous valve incompetence and thrombosis is bidirectional, as incompetent venous valves promote venous stasis and thereby thrombus formation [119]. Remodeling of the vein wall in the post-thrombotic syndrome is more extensive in elderly people [120]. Timely removal of the thrombus may improve deep venous flow and hence decrease the incidence of postthrombotic syndrome. Patients treated with new oral anticoagulants (including dabigatran, rivaroxaban, apixaban, and edoxaban) or percutaneous endovenous intervention for lower extremity deep venous thrombosis showed lower incidence of post-thrombotic syndrome and reduced recurrent deep vein thrombosis and venous obstruction [121] [122]. Endovascular methods have been developed as an aggressive treatment for lower-extremity deep vein thromboses that can remove acute venous thrombus and facilitate stent treatment of underlying venous stenoses [123]. These involve catheter-directed thrombolysis and percutaneous mechanical thrombectomy, balloon venoplasty, iliac vein stenting, and manual aspiration [124]. The lysis of endovascular thrombus results is a more rapid thrombus dissolution than systemic thrombolysis, thereby preserving valvular function [125]. The most important and most frequent complication of catheter-based interventions in patients with deep vein thrombosis is bleeding, mostly related to the use of thrombolytic agents [126].

\section{Chronic venous disease - varicose veins}

Chronic venous disease of the lower limbs is manifested as a progressive impairment of the venous circulation of the tissues [82]. The clinical signs of chronic venous disease range from edema, venous eczema, hyperpigmentation of skin, and lipodermatosclerosis (induration caused by fibrosis of the subcutaneous fat) to varicose veins and venous ulcers [82]. Chronic venous disease can be graded according to the descriptive Clinical, Etiological, Anatomical, Pathophysiological (CEAP) classification [82]. The clinical signs are categorized into seven classes (designated $\mathrm{C} 0$ to $\mathrm{C6}$ ) according to severity [82]: no visible or palpable signs of venous disease $(\mathrm{C} 0)$, telangiectasias or reticular veins $(\mathrm{C} 1)$, varicose veins $(\mathrm{C} 2)$, edema (C3), pigmentation or eczema (C4a), lipodermatosclerosis or atrophie blanche $(\mathrm{C} 4 \mathrm{~b})$, healed venous ulcer (C5), and active venous ulcer (C6). Varicose veins are dilated, thickened, elongated, and twisted blood vessels, whose ability to control organ blood flow is impaired. Varicosities are present from class 2 of chronic venous disease. Severe chronic venous disease (C4 to $\mathrm{C} 6$ ) is termed "chronic venous insufficiency," which is characterized by the presence of skin alterations in addition to varicose veins [82].

Advanced age, obesity, family history, and a sedentary lifestyle represent major risk factors for the development of chronic venous disease [82]. Severity of chronic venous disease progresses with advanced age [82]. The Framingham Study showed that the incidence of chronic venous disease is higher among women than men [4]. Women with varicose veins are more often obese, have lower levels of physical activity, and have higher systolic blood pressure. Men with varicose veins are characterized by lower levels of physical activity and higher smoking rates [4]. Although the pathomechanism of chronic venous disease is not entirely known, it is characterized with venous hypertension, venous reflux, and venous wall inflammation and fibrosis that can progress in a vicious circle of inflammation resulting in further progression of venous hypertension, venous reflux, and production of inflammatory mediators [82]. In the Edinburgh Vein Study, venous reflux increased the risk of developing varicose veins, especially when combined deep and superficial reflux was present $[4$, 8].

The mechanisms by which aging exacerbates progression of chronic venous disease are multifaceted. There is a general thickening of the venous wall with aging, even without the presence of reflux or venous hypertension [127]. Spatial heterogeneity in PDGF 
production within the aged venous wall has been causally linked to tortuosity [128]. Chronic venous hypertension initiates a range of pathophysiologic changes in the venous wall and surrounding tissues including inflammation, and increased permeability of endothelium. The resulting accumulation of fibrin and hemosiderin in the perivascular tissues acts to exacerbate inflammation and promote collagen synthesis by fibroblasts leading to venous wall thickening and remodeling. Tissue hypoxia leads to apoptosis and extracellular changes [129]. Aging-induced inflammation in veins is associated with elevated cytokine production [130] and increased MMP activation, which likely play a critical role in the pathogenesis of chronic venous disease [131, 132].

The effects of sex hormones on venous diseases

Sex differences in the pathogenesis of venous diseases have been extensively studied [133]. Female sex is associated with greater risk factors for varicosis [133]. Lower limb venous pressure depends on the degree of calf muscle mass and activity and body mass index. Females have lower resting venous pressures because females, in general, have smaller calf size than males [134, 135]. The progression of chronic venous disease in the Edinburgh Vein population-based cohort study did not differ by sex, but family history of varicose veins or deep venous thrombosis increased the risk of disease progression [136]. The prevalence of deep vein thrombosis was higher in males. Similarly, the Austrian Study of Recurrent Venous Thromboembolism showed that men had a 3.6-fold higher risk of recurrent venous thrombosis than women $[137,138]$. There are strong data suggesting that both estrogen and testosterone signaling pathways modulate biological processes involved in venous thrombosis [139-141]. Important in that regard is that women using exogenous estrogens either as contraceptives or as post-menopausal hormonal replacement have a higher risk of venous thrombosis [142-144].

\section{Role of veins in vascular cognitive impairment in aging}

There is increasing evidence supporting an important role of age-related functional and structural alterations in cerebral veins in the pathogenesis of vascular cognitive impairment and dementia (VCID) [145]. Pathophysiological consequences of aginginduced dysregulation of the cerebral venous circulation potentially include disruption of the blood-brain barrier, development of cerebral microhemorrhages of venous origin, altered production of cerebrospinal fluid, glymphatic dysfunction, and dysregulation of cerebral blood flow [145].

Aging is known to alter the structure of cerebral veins, resulting in increased collagenosis [146, 147]. Increased venous collagenosis was demonstrated in brains with manifest leukoaraiosis [147], suggesting that pathological remodeling of the venous wall may contribute to the genesis of white matter lesions [148]. Recent studies started to determine how imaging alterations of deep medullary veins, small vessel disease, and cognitive impairment in older adults associate $[149,150]$. There is emerging evidence that the increased diameter of the internal cerebral veins and of the basal veins of Rosenthal in older adults associate with regional white matter disease [150]. Periventricular venous collagenosis was reported to associate with white matter hyperintensities in both $\mathrm{AD}$ patients in older adults without $\mathrm{AD}$ pathologies [148]. In the aged, brain venules often exhibit increased tortuosity $[151,152]$. It has been proposed that venular tortuosity may be an early neuroimaging marker of small vessel disease and may correlate with white matter hyperintensities and/or cerebral microhemorrhages [152]. A recent brain imaging study comparing deep medullary veins showed that patients with early Alzheimer's disease also exhibit increased venular tortuosity [153]. The mechanisms contributing to exacerbated venous tortuosity in the brain are likely multifaceted and, based on analog mechanisms manifested in the peripheral venous circulation, may include elevated cerebral venular pressure (similar to the role of increased venous pressure in formation of varicose veins in the lower extremities [154]), altered elasticity of the vascular wall, degenerative changes of the media, and pathological remodeling of the extracellular matrix and basal membrane [151].

Age-related structural alterations of the bridging veins, which connect the superficial venous network to dural sinuses, have an important role in subdural bleedings associated with traumatic brain injury in older adults [155]. Because of brain atrophy and consequential expansion of the subdural space, 
elevated mechanical tension is imposed on the bridging veins in older individuals $[155,156]$. The resulting increased mechanical burden combined with the aging-induced decrease in the elasticity of the venous wall predispose these bridging veins to a mechanically induced rupture in response to even minor brain trauma, resulting in increased incidence of bleedings into the subdural space in the elderly even with minor trauma $[155,156]$.

There is ample evidence documenting aginginduced degenerative changes and pathological remodeling in venous valves [81], which potentially contribute to venous valve insufficiency associated with advanced aging [77, 78]. On the basis of our understanding of the pathogenesis of chronic venous insufficiency in the peripheral venous circulation, it can be predicted that aging-induced alterations in cerebral venous valves also contribute to valvular incompetence [157], promoting venous reflux and cerebral venous hypertension. Elevated cerebral venous pressure has been proposed to contribute to pathological processes including microhemorrhages of venous origin, blood-brain barrier disruption, and perivascular inflammation, all of which promote age-related cognitive decline [145, 158, 159]. When venous hypertension develops in the superior sagittal sinus, it also impairs the absorption of the cerebrospinal fluid.

The internal jugular vein valve, which is the only venous valve situated in the venous circulation between the heart and the brain, is critical for the prevention of retrograde flow of venous blood. A missing or damaged internal jugular vein valve may promote jugular venous reflux [160]. There is strong anatomical evidence that the internal jugular vein valve is often incompetent in older adults. With an incompetent internal jugular vein valve, increases in intrathoracic pressure due to Valsalva maneuvers for example result in jugular venous reflux [161]. The incidence of jugular venous reflux significantly increases with advanced age [162-167], as a consequence of aginginduced degenerative changes in the venous valves. Jugular valve insufficiency and jugular venous reflux likely contribute to various brain pathologies [168, 169], including intra-cerebral hemorrhages of venous origin [170].

Cerebral white matter hyperintensities (WMHs) are a common radiological finding on MRI imaging of the aging brain showing damage in the white matter regions near the lateral ventricles ("leukoaraiosis") [171-174]. WMHs can be diagnosed on T2-weighted fluid inversion recovery (FLAIR) sequences, without significant hypointensity on T1 images. The clinical significance of WMHs stems from their association with vascular cognitive impairment [175-177] as well as Alzheimer's disease [178-181] in older adults. In addition to the well-documented contribution of pathological alterations in the arterial circulation (e.g., microvascular consequences of arterial hypertension), there is also increasing evidence supporting the role of aging-induced venous pathologies in the genesis of WMHs [182]. A number of age-related venous abnormalities were shown to associate with WMHs [146, 182], including jugular venous reflux and increased cerebral venous pressure [183].

Cerebral microhemorrhages (CMHs, also known as "cerebral microbleeds"), which result from rupture of small intracerebral blood vessels, are highly prevalent in older adults [159]. CMHs were reported to contribute to the pathogenesis of cognitive decline [159, 184-192]. In addition to the well-characterized arteriolar origin of CMHs, there is emerging evidence that CMHs can also originate from the rupturing of small veins, venules, and capillaries [159, 193-195]. Studies linking the development of CMHs to the performance of Valsalva maneuvers [196] support this concept. During the Valsalva maneuver, intrathoracic pressure can increase over $150 \mathrm{mmHg}$ [197], which can be transmitted to the cerebral venous circulation if the internal jugular vein valves are incompetent [161, 198-201]. It has been proposed that when the pressure in the thin-walled cerebral venules exceeds a critical limit, multifocal venous $\mathrm{CMHs}$ may ensue in older adults.

Research into the pathogenesis of cerebral amyloid angiopathy has been primarily focused on $A \beta$ deposition in the wall of arterial vessels. Yet, there is also increasing evidence from preclinical studies and clinical investigations that veins and venules are also affected by accumulation of $A \beta$ likely through impaired perivascular clearance [202, 203]. It has been proposed that venular amyloidosis exacerbates microvascular pathologies associated with $\mathrm{AD}$ and may promote the development of amyloid plaques in the brain parenchyma as well [203]. 


\section{Aging veins as grafts}

A special issue associated with vein aging relates to the surgical application of venous grafts for arterial bypasses. Saphenous veins have been used for coronary artery bypass grafting for more than 50 years. The advantages of this approach include ease of access, ease of operation, sufficiency of length for transplantation, and shortness of harvest time [204]. Vein grafts are living conduits which respond to hemodynamical and other local environmental stimuli. The transposition of vein segments from venous low pressure and low flow circumstances to arterial high pressure and high flow environment results in structural and functional remodeling of the venous wall. This remodeling can be either physiological or pathological, but the underlying regulatory mechanisms are not well understood.

The venous tunica media layer may become damaged during bypass grafting [205]. Vascular smooth muscle cells convert from contractile to synthetic phenotype as a consequence of damage. Altered shear, circumferential, longitudinal, compressive, and pulsatile stresses induce smooth muscle migration and proliferation into the intima, and deposition of collagen and proteoglycans into the intima and tunica media leading to thickening of these two layers [206]. The inward/outward luminal and wall remodeling of venous grafts leads to "arterialized veins" with altered structural and biomechanical features as compared to "normal" veins. Early studies showed that the lumen of venous bypass grafts may increase by 25 to $75 \%$ due to this adaptive remodeling [207]. The time course of venous graft remodeling is relatively rapid, the majority of the luminal and wall remodeling of the graft occurs in the first month after implantation [207]. The PREVENT III and IV randomized controlled trials showed that $30-40 \%$ of coronary and lower extremity vein grafts develop significant stenosis within the first year following implantation [205, 208].

There is evidence that grafting with veins from older adults is less successful than with younger veins [209-211]. Potential mechanisms contributing to pathological remodeling of older vein grafts include the dysregulated expression of Notch-4 [212], Ephr-B4 [213], smooth muscle myosin heavy chain, calponin, TIMP-2 and TIMP-3, cytokeratin-8, and MMPs [44].

\section{Shared mechanisms of vascular aging affecting the venous system}

The role of shared cellular and molecular mechanisms of aging in age-related alterations of the venous system has not been studied in detail and can be inferred from studies on arterial aging [9, 10, 24]. Here we highlight some of these critical shared mechanisms of vascular aging, which may be targeted in future experimental and clinical studies for prevention of age-related venous alterations.

Increased oxidative and nitrative stress

Strong evidence implicates increased oxidative stress in vascular aging processes, including the genesis of endothelial dysfunction and pathological vascular remodeling [22, 25, 30, 214-223]. Vascular oxidative stress results in impaired bioavailability of $\mathrm{NO}$ and increased generation of the highly reactive oxidant peroxynitrite $\left(\mathrm{ONOO}^{-}\right.$; the reaction product of $\mathrm{NO}$ and superoxide). There is evidence that aging results in increased presence of nitrotyrosine (a marker of increased $\mathrm{ONOO}^{-}$formation) in endothelial cells obtained from the antecubital veins [22], consistent with the view that increased oxidative and nitrative stress is a critical feature of venous aging. NO exerts potent anti-inflammatory, anti-thrombotic, and anti-leukocyte adhesion effects; thus, reduction in $\mathrm{NO}$, in addition to the direct pro-inflammatory effects of increased levels of reactive oxygen species, likely contributes to age-related venous pathologies. Increased vascular oxidative stress has also been linked to activation of matrix metalloproteinases (MMPs) and consequential disruption of the structural integrity of aged vessels.

Increased cellular senescence

Cellular senescence is emerging as an important mechanism of aging-induced vascular impairment [224, 225]. Oxidative stress-induced DNA damage is an important mechanism contributing to cellular senescence. Senescent endothelial cells express a senescence-associated secretory phenotype (SASP), characterized by increased secretion of inflammatory cytokines, immune modulators, growth factors, and proteases. There are studies supporting the concept that endothelial senescence is also a feature of venous 
aging [226]. Future studies are needed to define the role of senescence and SASP factors in the pathogenesis of venous alterations in aging.

Increased inflammatory status

There is a strong connection between aging and chronic sterile inflammation in the cardiovascular system [10, 25, 27, 28, 217, 227-231]. The mechanisms contributing to age-related sterile vascular inflammation are likely multifaceted. Importantly, increased production of ROS activates pro-inflammatory signaling pathways, including NF- $\mathrm{KB}$ [222], which promote endothelial activation and up-regulate expression of various pro-inflammatory paracrine mediators. Aged venous endothelial cells also exhibit a pro-inflammatory phenotype, including an increased activation of NF-кB [22, 232]. Additionally, senescent cells also contribute to vascular inflammation via their SASP. Heightened inflammatory status likely contributes to pathological remodeling of aged veins $[11,38]$.

Increased vascular apoptosis

Apoptosis is an evolutionarily conserved cell death program which was shown to contribute to a range of vascular aging phenotypes [10, 233]. In the aged arterial system, there is an increased presence of apoptotic endothelial cells, which has been linked to impaired bioavailability of pro-survival NO, increased levels of the pro-apoptotic inflammatory cytokine TNF $\alpha$, and/or increased mitochondrial oxidative stress [29, 234-236]. Apoptosis also likely contributes to the pathogenesis of age-related venous diseases. Increased presence of apoptotic endothelial and smooth muscle cells was documented in varicose veins removed from older patients [40]. Recent observations confirmed the presence of apoptotic cells in the venous wall in chronic venous insufficiency [237].

\section{Role of sirtuins}

Sirtuins (including SIRT1, SIRT3) are $\mathrm{NAD}^{+}$-dependent protein deacetylases, which regulate important cellular pathways involved in regulation of mitochondrial energy metabolism, cellular metabolic processes, chromatin function, and gene transcription [238-241]. There is strong evidence suggesting that sirtuin activation exerts anti-aging effects in the arterial system [242-245]. $\mathrm{NAD}^{+}$is a rate-limiting co-substrate for sirtuins. Cellular $\mathrm{NAD}^{+}$levels are decreased in advanced aging [246, 247], at least in part, as a consequence of increased $\mathrm{NAD}^{+}$utilization by overactivated PARP-1 enzyme [248]. Recent studies suggest that in mouse models of aging, treatments that boost $\mathrm{NAD}^{+}$biosynthesis (e.g., administration of nicotinamide mononucleotide, a key $\mathrm{NAD}^{+}$precursor [246]) can activate sirtuins and reverse aging-induced endothelial dysfunction in the arterial system [23, 34]. Initial evidence suggests that interventions that activate SIRT1 or SIRT3 likely exert beneficial effect on the aged venous system as well [249, 250].

Impaired cellular stress resilience

Impaired cellular stress resilience (the impaired ability of vascular cells to counteract the deleterious effects of various molecular stresses and return to homeostasis) has been identified as a universal hallmark of the aging process. In young organisms in the presence of increased production of ROS, adaptive homeostatic mechanisms are invoked, including the Nrf2 (nuclear factor erythroid 2-related factor 2)-driven antioxidant defense pathways [251-253]. Nrf2 is a redox-sensitive transcription factor, which orchestrates the antioxidant response [254]. In the young vasculature, this adaptive homeostatic mechanism up-regulates the expression of antioxidant enzymes and proteins that repair ROS-induced macromolecular damage, thereby protecting cells against oxidative injury triggered by dietary and lifestyle factors (e.g., smoking), diabetes mellitus, and inflammation. Importantly, Nrf2 activation has been shown to protect venous endothelial cells from oxidative stress-mediated apoptosis and injury [255-259]. Nrf2 activation was also demonstrated to confer potent anti-inflammatory [260] effects. Aging is associated with Nrf2 dysfunction in the vascular system, exacerbating oxidative stress and its sequela, including increased inflammation and cellular senescence [251, 252, 261]. Age-related loss of oxidative stress resilience is thought to promote development of vascular pathologies [262]. Recent studies provide preliminary evidence that mutations in the Nrf2 pathway may associate with deep vein thrombosis [263]. Further studies are warranted to determine how age-related Nrf2 dysfunction contributes to the genesis of venous 
aging phenotypes and to investigate the potential beneficial venous effects of pharmacological Nrf2 activators.

\section{mTOR signaling}

Cellular mTOR signaling is an important regulator of metabolic processes including autophagy. Reduced activity of the mTOR pathway is well-documented to regulate aging processes [264]. There is growing evidence that experimental inhibition of mTOR activity (e.g., by rapamycin) interferes with the pathogenesis of a range of age-related diseases [265, 266] and exerts anti-aging endothelial protective effects [266-273]. Preliminary evidence also implicates mTOR in the pathogenesis of chronic venous insufficiency [274]. DEPTOR (domain-containing mTOR interacting protein) is involved in mTOR signaling pathway as an endogenous regulator. Recent studies demonstrate that overexpression of DEPTOR results in marked phenotypic changes in human saphenous vein endothelial cells [275].

\section{Interventions for healthy vein aging}

Results from the Framingham Study suggest that increased physical activity and weight control may help prevent varicose veins among adults at high risk [90]. For prevention of deep vein thrombosis in older adults, lifestyle changes are warranted including increasing physical activity, ceasing to smoking, and reducing excess bodyweight. Conservative and interventional treatments can improve health-related quality of life and diminish or delay symptoms and progression of chronic venous insufficiency. Compression stockings are used to relieve symptoms; however, the compliance to wear them is not always adequate. Venoactive drugs may slow progression of chronic venous disease, but in advanced clinical stages aggressive medical intervention is needed. Thromboprophylaxis in high-risk states, such as immobilization and surgery, is mandatory. Furthermore, temporary anticoagulant therapy is needed in the case of venous thrombosis, while in the case of recurrent venous thrombosis or predisposing factor, lifelong anticoagulation is recommended. With the accessibility of molecular technologies, the time is not far when point-of-care testing will become available to identify thrombophilic genetic disorders, including mutations affecting the function of cells in venous wall, leading to early and proper prevention. Very long chain n-3 fatty acids in the diet lower thrombotic tendency, and flavonoids decrease platelet aggregation [276]. Because of the high global prevalence, screening and education programs for general practitioners have high importance [129, 277]. Moderate physical exercise seems to be one of the most effective means of prevention $[4,67,96]$.

\section{Perspectives}

There is growing evidence supporting the paradigm of the plasticity of vascular aging, suggesting that vascular aging phenotypes can be reversed by pharmacological or dietary interventions [23, 226, 235, 278-280]. It is predicted that in the upcoming decade, interventional strategies using combination treatments targeting multiple vascular aging processes can be developed to promote vascular rejuvenation. These will likely also be effective in improving venous health and preventing the pathogenesis of venous diseases in older adults. Public health research should also investigate the determinants of pathological venous aging (including the interaction of genetic, environmental, lifestyle, dietary, and socio-economic factors). Critical areas of venous aging research include mechanistic investigations targeting the contributions of venous pathologies to age-related cognitive impairment and neurodegeneration.

Acknowledgements The study has been supported by Hungarian National grants OTKA TO 32019 and OTKA TO 42670 and by a grant from the Dean of the Semmelweis University, Faculty of Medicine. Prof. Zoltan Varady, MD (Venenklinik Frankfurt-am-Main, Germany), and Imre Bihari, MD (A+B Clinic, Budapest, Hungary), are acknowledged for their advice and helpful comments.

Project no. NVKP_16-1-2016-0017 ("National Heart Program") has been implemented with the support provided from the National Research, Development and Innovation Fund of Hungary, financed under the NVKP_16 funding scheme. The research was financed by the Thematic Excellence Programme (2020-4.1.1.-TKP2020) of the Ministry for Innovation and Technology in Hungary, within the framework of the Therapeutic Development and Bioimaging thematic programmes of the Semmelweis University.

The concept of this review paper was originally conceived by Professor Emil Monos $\uparrow$. This paper is dedicated to his memory. 
Funding Open access funding provided by Semmelweis University.

\section{Declarations}

Competing interests Zoltan Ungvari, $\mathrm{MD}, \mathrm{PhD}$, is serving as Consulting Editor of the American Journal of PhysiologyHeart and Circulatory Physiology and Editor-in-Chief of GeroScience.

Open Access This article is licensed under a Creative Commons Attribution 4.0 International License, which permits use, sharing, adaptation, distribution and reproduction in any medium or format, as long as you give appropriate credit to the original author(s) and the source, provide a link to the Creative Commons licence, and indicate if changes were made. The images or other third party material in this article are included in the article's Creative Commons licence, unless indicated otherwise in a credit line to the material. If material is not included in the article's Creative Commons licence and your intended use is not permitted by statutory regulation or exceeds the permitted use, you will need to obtain permission directly from the copyright holder. To view a copy of this licence, visit http://creativecommons.org/licenses/by/4.0/.

\section{References}

1. Health, United States, 2016: with chartbook on longterm trends in health Hyattsville (MD); 2017.

2. Barnes GD, Gafoor S, Wakefield T, Upchurch GR Jr, Henke P, Froehlich JB. National trends in venous disease. J Vasc Surg. 2010;51:1467-73.

3. Bradbury A, Evans C, Allan P, Lee A, Ruckley CV, Fowkes FG. What are the symptoms of varicose veins? Edinburgh vein study cross sectional population survey. BMJ. 1999;318:353-6.

4. Brand FN, Dannenberg AL, Abbott RD, Kannel WB. The epidemiology of varicose veins: the Framingham Study. Am J Prev Med. 1988;4:96-101.

5. Cesarone MR, Belcaro G, Nicolaides AN, Geroulakos G, Griffin M, Incandela L, De SM, Sabetai M, Geroulakos G, Agus G, Bavera P, Ippolito E, Leng G, Di RA, Cazaubon M, Vasdekis S, Christopoulos D, Veller M. 'Real' epidemiology of varicose veins and chronic venous diseases: the San Valentino Vascular Screening Project. Angiology. 2002;53:119-30.

6. Evans CJ, Fowkes FG, Ruckley CV, Lee AJ. Prevalence of varicose veins and chronic venous insufficiency in men and women in the general population: Edinburgh Vein Study. J Epidemiol Community Health. 1999;53:149-53.

7. Robertson L, Evans C, Fowkes FG. Epidemiology of chronic venous disease. Phlebology. 2008;23:103-11.

8. Robertson LA, Evans CJ, Lee AJ, Allan PL, Ruckley CV, Fowkes FG. Incidence and risk factors for venous reflux in the general population: Edinburgh Vein Study. Eur J Vasc Endovasc Surg. 2014;48:208-14.
9. Ungvari Z, Tarantini S, Sorond F, Merkely B, Csiszar A. Mechanisms of vascular aging, a geroscience perspective: JACC Focus Seminar. J Am Coll Cardiol. 2020;75:931-41.

10. Ungvari Z, Tarantini S, Donato AJ, Galvan V, Csiszar A. Mechanisms of vascular aging. Circ Res. 2018;123:849-67.

11. Pascual G, Mendieta C, Garcia-Honduvilla N, Corrales C, Bellon JM, Bujan J. TGF-beta1 upregulation in the aging varicose vein. J Vasc Res. 2007;44:192-201.

12 Vuylsteke ME, Colman R, Thomis S, Guillaume G, Degrande E, Staelens I. The influence of age and gender on venous symptomatology An epidemiological survey in Belgium and Luxembourg. Phlebology. 2016;31(325):33

13. Donato AJ, Machin DR, Lesniewski LA. Mechanisms of dysfunction in the aging vasculature and role in agerelated disease. Circ Res. 2018;123:825-48.

14. Childs BG, Li H, van Deursen JM. Senescent cells: a therapeutic target for cardiovascular disease. J Clin Invest. 2018;128:1217-28.

15. Lakatta EG, Levy D. Arterial and cardiac aging: major shareholders in cardiovascular disease enterprises: part I: aging arteries: a "set up" for vascular disease. Circulation. 2003;107:139-46.

16. Monos E, Lóránt M, Dörnyei G, Bérczi V, Nádasy G. Long-term adaptation mechanisms in extremity veins supporting orthostatic tolerance. News Physiol Sci. 2003;18:210-4.

17. Smeets MWJ, Mourik MJ, Niessen HWM, Hordijk PL. Stasis promotes erythrocyte adhesion to von Willebrand factor. Arterioscler Thromb Vasc Biol. 2017;37:1618-27.

18. C.G Caro TJP, R.C Schroter, and W.A. Seed. The mechanics of the circulation; 1978.

19. Cooper K. Structure and function of the circulation. Plenum, New York. 1981;II:457-85.

20. Lim CS, Davies AH. Pathogenesis of primary varicose veins. Br J Surg. 2009;96:1231-42.

21. Bochenek ML, Schütz E, Schäfer K. Endothelial cell senescence and thrombosis: ageing clots. Thromb Res. 2016;147:36-45.

22. Donato AJ, Eskurza I, Silver AE, Levy AS, Pierce GL, Gates PE, Seals DR. Direct evidence of endothelial oxidative stress with aging in humans: relation to impaired endothelium-dependent dilation and upregulation of nuclear factor-kappaB. Circ Res. 2007;100:1659-66.

23. Tarantini S, Valcarcel-Ares MN, Toth P, Yabluchanskiy A, Tucsek Z, Kiss T, Hertelendy P, Kinter M, Ballabh P, Sule Z, Farkas E, Baur JA, Sinclair DA, Csiszar A, Ungvari Z. Nicotinamide mononucleotide (NMN) supplementation rescues cerebromicrovascular endothelial function and neurovascular coupling responses and improves cognitive function in aged mice. Redox Biol. 2019;24:101192.

24. Csiszar A, Tarantini S, Yabluchanskiy A, Balasubramanian P, Kiss T, Farkas E, Baur JA, Ungvari Z. Role of endothelial $\mathrm{NAD}(+)$ deficiency in age-related vascular dysfunction. Am J Physiol Heart Circ Physiol. 2019;316:H1253-66. 
25. Csiszar A, Gautam T, Sosnowska D, Tarantini S, Banki E, Tucsek Z, Toth P, Losonczy G, Koller A, Reglodi D, Giles CB, Wren JD, Sonntag WE, Ungvari Z. Caloric restriction confers persistent anti-oxidative, pro-angiogenic, and anti-inflammatory effects and promotes antiaging miRNA expression profile in cerebromicrovascular endothelial cells of aged rats. Am J Physiol Heart Circ Physiol. 2014;307:H292-306.

26. Ungvari Z, Tucsek Z, Sosnowska D, Toth P, Gautam T, Podlutsky A, Csiszar A, Losonczy G, Valcarcel-Ares MN, Sonntag WE. Aging-induced dysregulation of Dicer1-dependent microRNA expression impairs angiogenic capacity of rat cerebromicrovascular endothelial cells. J Gerontol A Biol Sci Med Sci. 2013;68:877-91.

27. Csiszar A, Labinskyy N, Jimenez R, Pinto JT, Ballabh P, Losonczy G, Pearson KJ, de Cabo R, Ungvari Z. Antioxidative and anti-inflammatory vasoprotective effects of caloric restriction in aging: role of circulating factors and SIRT1. Mech Ageing Dev. 2009;130(8):518-27.

28. Ungvari Z, Orosz Z, Labinskyy N, Rivera A, Xiangmin Z, Smith K, Csiszar A. Increased mitochondrial H2O2 production promotes endothelial NF-kappaB activation in aged rat arteries. Am J Physiol Heart Circ Physiol. 2007;293:H37-47.

29. Csiszar A, Ungvari Z, Koller A, Edwards JG, Kaley G. Proinflammatory phenotype of coronary arteries promotes endothelial apoptosis in aging. Physiol Genomics. 2004;17:21-30.

30. Csiszar A, Ungvari Z, Edwards JG, Kaminski PM, Wolin MS, Koller A, Kaley G. Aging-induced phenotypic changes and oxidative stress impair coronary arteriolar function. Circ Res. 2002;90:1159-66.

31. Erusalimsky JD. Vascular endothelial senescence: from mechanisms to pathophysiology. J Appl Physiol. 1985;2009(106):326-32.

32. Hayashi T, Matsui-Hirai H, Miyazaki-Akita A, Fukatsu A, Funami J, Ding QF, Kamalanathan S, Hattori Y, Ignarro LJ, Iguchi A. Endothelial cellular senescence is inhibited by nitric oxide: implications in atherosclerosis associated with menopause and diabetes. Proc Natl Acad Sci U S A. 2006;103:17018-23.

33. Donato AJ, Gano LB, Eskurza I, Silver AE, Gates PE, Jablonski K, Seals DR. Vascular endothelial dysfunction with aging: endothelin-1 and endothelial nitric oxide synthase. Am J Physiol Heart Circ Physiol. 2009;297:H425-32.

34. de Picciotto NE, Gano LB, Johnson LC, Martens CR, Sindler AL, Mills KF, Imai S, Seals DR. Nicotinamide mononucleotide supplementation reverses vascular dysfunction and oxidative stress with aging in mice. Aging Cell. 2016;15:522-30.

35. Radovits T, Seres L, Gero D, Berger I, Szabo C, Karck M, Szabo G. Single dose treatment with PARP-inhibitor INO-1001 improves aging-associated cardiac and vascular dysfunction. Exp Gerontol. 2007;42:676-85.

36. Wali MA, Eid RA. Intimal changes in varicose veins: an ultrastructural study. J Smooth Muscle Res. 2002;38:63-74.

37. Tisato V, Zauli G, Voltan R, Gianesini S, di Iasio MG, Volpi I, Fiorentini G, Zamboni P, Secchiero P. Endothelial cells obtained from patients affected by chronic venous disease exhibit a pro-inflammatory phenotype. PLoS ONE. 2012;7:e39543.

38. Jacob T, Hingorani A, Ascher E. Overexpression of transforming growth factor-betal correlates with increased synthesis of nitric oxide synthase in varicose veins. J Vasc Surg. 2005;41:523-30.

39. Pacher P, Beckman JS, Liaudet L. Nitric oxide and peroxynitrite in health and disease. Physiol Rev. 2007;87:315-424.

40. Simovart HE, Aunapuu M, Lieberg J, Roosaar P, Arend A. Age-related changes in apoptosis and expressions of intercellular adhesion molecule- 1 and vascular endothelial growth factor receptor type 2 in the wall of varicose veins. Int Angiol. 2010;29:507-13.

41. Fonseca C, Taatjes DJ, Callas P, Ittleman F, Bovill EG. The effects of aging on the intimal region of the human saphenous vein: insights from multimodal microscopy and quantitative image analysis. Histochem Cell Biol. 2012;138:435-45.

42. Drubaix I, Giakoumakis A, Robert L, Robert AM. Preliminary data on the age-dependent decrease in basic fibroblast growth factor and platelet-derived growth factor in the human vein wall and in their influence on cell proliferation. Gerontology. 1998;44:9-14.

43. Aunapuu M, Arend A. Histopathological changes and expression of adhesion molecules and laminin in varicose veins. Vasa. 2005;34:170-5.

44. Perek B, Malinska A, Gasowski J, Ostalska-Nowicka D, Perek A, Jemielity M, Zabel M, Nowicki M. Potentially positive ageing-related variations of medial smooth muscle cells in the saphenous veins used as aortocoronary bypass grafts. Folia Histochem Cytobiol. 2016;54:91-8.

45. Xu Y, Bei Y, Li Y, Chu H. Phenotypic and functional transformation in smooth muscle cells derived from varicose veins. J Vasc Surg Venous Lymphat Disord. 2017;5:723-33.

46. Ascher E, Jacob T, Hingorani A, Gunduz Y, Mazzariol F, Kallakuri S. Programmed cell death (apoptosis) and its role in the pathogenesis of lower extremity varicose veins. Ann Vasc Surg. 2000;14:24-30.

47. Bujan J, Jimenez-Cossio JA, Jurado F, Gimeno MJ, Pascual G, Garcia-Honduvilla N, Dominguez B, Bellon JM. Evaluation of the smooth muscle cell component and apoptosis in the varicose vein wall. Histol Histopathol. 2000;15:745-52.

48. Ducasse E, Giannakakis K, Chevalier J, Dasnoy D, Puppinck P, Speziale F, Fiorani P, Faraggiana T. Dysregulated apoptosis in primary varicose veins. Eur $\mathrm{J}$ Vasc Endovasc Surg. 2005;29:316-23.

49. Li H, Han W, Wang L, Chu H, Xu Y, Wang T, Tang J, Li K, Zhao J. Assessment of apoptotic cells in the wall of thrombophlebitic saphenous vein. Phlebology. 2016;31:216-21.

50. Yongbo X, Wei H, Lei W, Jianhua Z, Tao W, Jinyuan T, Kun L, Haibo C. Changes in levels of apoptosis in the walls of different segments of great saphenous varicose veins. Phlebology. 2016;31:632-9.

51. Urbanek T, Skop B, Wiaderkiewicz R, Wilczok T, Ziaja K, Lebda-Wyborny T, Pawlicki K. Smooth muscle cell apoptosis in primary varicose veins. Eur J Vasc Endovasc Surg. 2004;28:600-11. 
52. Wali MA, Eid RA. Changes of elastic and collagen fibers in varicose veins. Int Angiol. 2002;21:337-43.

53. Bouissou H, Maurel E. Collagens of the internal saphenous vein, normal and varicose, as a function of age. Bull Acad Natl Med. 1991;175:603-6 (discussion 607).

54. Barallobre-Barreiro J, Oklu R, Lynch M, Fava M, Baig F, Yin X, Barwari T, Potier DN, Albadawi H, Jahangiri M, Porter KE, Watkins MT, Misra S, Stoughton J, Mayr M. Extracellular matrix remodelling in response to venous hypertension: proteomics of human varicose veins. Cardiovasc Res. 2016;110:419-30.

55. Jacob MP, Badier-Commander C, Fontaine V, Benazzoug Y, Feldman L, Michel JB. Extracellular matrix remodeling in the vascular wall. Pathol Biol (Paris). 2001;49:326-32.

56. Kockx MM, Knaapen MW, Bortier HE, Cromheeke KM, Boutherin-Falson O, Finet M. Vascular remodeling in varicose veins. Angiology. 1998;49:871-7.

57. Porto LC, Azizi MA, Pelajo-Machado M, Matos da SP and Lenzi HL. Elastic fibers in saphenous varicose veins. Angiology. 2002;53:131-40.

58. Rose SS, Ahmed A. Some thoughts on the aetiology of varicose veins. J Cardiovasc Surg (Torino). 1986;27:534-43.

59. Bujan J, Gimeno MJ, Jimenez JA, Kielty CM, Mecham RP, Bellon JM. Expression of elastic components in healthy and varicose veins. World J Surg. 2003;27:901-5.

60. Pascual G, Mendieta C, Mecham RP, Sommer P, Bellón JM, Buján J. Down-regulation of lysyl oxydase-like in aging and venous insufficiency. Histol Histopathol. 2008;23:179-86.

61. Robert L, Labat-Robert J. Longevity and aging: role of genes and of the extracellular matrix. Biogerontology. 2015;16:125-9.

62. Greaney JL, Farquhar WB. Why do veins stiffen with advancing age? J Appl Physiol. 1985;2011(110):11-2.

63. Berczi V, Molnar AA, Apor A, Kovacs V, Ruzics C, Varallyay C, Huttl K, Monos E, Nadasy GL. Non-invasive assessment of human large vein diameter, capacity, distensibility and ellipticity in situ: dependence on anatomical location, age, body position and pressure. Eur J Appl Physiol. 2005;95:283-9.

64. Olsen H, Länne T. Reduced venous compliance in lower limbs of aging humans and its importance for capacitance function. Am J Physiol. 1998;275:H878-86.

65. Zachrisson H, Lindenberger M, Hallman D, Ekman M, Neider D, Länne T. Diameter and compliance of the greater saphenous vein - effect of age and nitroglycerine. Clin Physiol Funct Imaging. 2011;31:300-6.

66. Gascho JA, Fanelli C, Zelis R. Aging reduces venous distensibility and the venodilatory response to nitroglycerin in normal subjects. Am J Cardiol. 1989;63:1267-70.

67. Monahan KD, Dinenno FA, Seals DR, Halliwill JR. Smaller age-associated reductions in leg venous compliance in endurance exercise-trained men. Am J Physiol Heart Circ Physiol. 2001;281:H1267-73.

68. Monos E, Berczi V, Nadasy G. Local control of veins: biomechanical, metabolic, and humoral aspects. Physiol Rev. 1995;75:611-66.

69. Hyland L, Docherty JR. An investigation of age-related changes in pre- and postjunctional alpha-adrenoceptors in human saphenous vein. Eur $\mathbf{J}$ Pharmacol. 1985;114:361-4.

70. Olsen H, Vernersson E, Länne T. Cardiovascular response to acute hypovolemia in relation to age. Implications for orthostasis and hemorrhage. Am J Physiol Heart Circ Physiol. 2000;278:H222-32.

71 Shi X, Wray DW, Formes KJ, Wang HW, Hayes PM, AH OY, Weiss MS, Reese IP. Orthostatic hypotension in aging humans. Am J Physiol Heart Circ Physiol. 2000;279:H1548-54.

72. Shiraki K, Sagawa S, Yousef MK, Konda N, Miki K. Physiological responses of aged men to headup tilt during heat exposure. J Appl Physiol. 1985;1987(63):576-81.

73. Tsutsui Y, Sagawa S, Yamauchi K, Endo Y, Yamazaki F, Shiraki K. Cardiovascular responses to lower body negative pressure in the elderly: role of reduced leg compliance. Gerontology. 2002;48:133-9.

74. Moore HD. Deep venous valves in the aetiology of varicose veins. Lancet. 1951;2:7-10.

75. Caggiati A. The venous valves of the lower limbs. Phlebolymphology. 2013;20:87-95.

76. Mühlberger D, Morandini L, Brenner E. An anatomical study of femoral vein valves near the saphenofemoral junction. J Vasc Surg. 2008;48:994-9.

77. Saphir O, Lev M. The venous valve in the aged. Am Heart J. 1952;44:843-50.

78. van Langevelde K, Sramek A, Rosendaal FR. The effect of aging on venous valves. Arterioscler Thromb Vasc Biol. 2010;30:2075-80.

79. Mouton WG, Wagner MO, Haenni B, Mouton KT, Ochs M, Tschanz SA. The influence of age on valve disease in patients with varicose veins analysed by transmission electron microscopy and stereology. Vasa. 2018;47:409-16.

80. Chopard RP, Miranda Neto MH, Biazotto W, Molinari SL. Age-related changes in the human renal veins and their valves. Ital J Anat Embryol. 1994;99:91-101.

81. Hemmeryckx B, Emmerechts J, Bovill EG, Hoylaerts MF, Lijnen HR. Effect of ageing on the murine venous circulation. Histochem Cell Biol. 2012;137:537-46.

82. Bergan JJ, Schmid-Schönbein GW, Smith PD, Nicolaides AN, Boisseau MR, Eklof B. Chronic venous disease. N Engl J Med. 2006;355:488-98.

83. Karasu A, Šrámek A, Rosendaal FR, van der Geest RJ, van Hylckama VA. Aging of the venous valves as a new risk factor for venous thrombosis in the elderly: the BATAVIA study. J Thromb Haemost. 2018;16:96-103.

84. Caggiati A, Bergan JJ, Gloviczki P, Eklof B, Allegra C, Partsch H. Nomenclature of the veins of the lower limb: extensions, refinements, and clinical application. J Vasc Surg. 2005;41:719-24.

85. Banjo AO. Comparative study of the distribution of venous valves in the lower extremities of black Africans and Caucasians: pathogenetic correlates of prevalence of primary varicose veins in the two races. Anat Rec. 1987;217:407-12.

86. Gottlob RMR. Venous Valves. New York: NYSpringer; 1986.

87. Cotton LT. Varicose veins Gross anatomy and development. Br J Surg. 1961;48(589):98. 
88. Sales CM, Rosenthal D, Petrillo KA, Jerivs HS, Matsuura J, Clark MD, Pontoriero MA, Syracuse DC, Luka NL. The valvular apparatus in venous insufficiency: a problem of quantity? Ann Vasc Surg. 1998;12:153-5.

89. Oger E. Incidence of venous thromboembolism: a community-based study in Western France. EPIGETBP Study Group. Groupe d'Etude de la Thrombose de Bretagne Occidentale. Thromb Haemost. 2000;83:657-60.

90. Wilkerson WR, Sane DC. Aging and thrombosis. Semin Thromb Hemost. 2002;28:555-68.

91. Anderson FA Jr, Wheeler HB, Goldberg RJ, Hosmer DW, Patwardhan NA, Jovanovic B, Forcier A, Dalen JE. A population-based perspective of the hospital incidence and case-fatality rates of deep vein thrombosis and pulmonary embolism. The Worcester DVT Study. Arch Intern Med. 1991;151:933-8.

92. Culmer DL, Diaz JA, Hawley AE, Jackson TO, Shuster KA, Sigler RE, Wakefield TW, Myers DD Jr. Circulating and vein wall $\mathrm{P}$-selectin promote venous thrombogenesis during aging in a rodent model. Thromb Res. 2013;131:42-8.

93. Wang YC, Colditz GA, Kuntz KM. Forecasting the obesity epidemic in the aging U.S. population. Obesity (Silver Spring). 2007;15:2855-65.

94. Balasubramanian P, Kiss T, Tarantini S, Nyul-Toth A, Ahire C, Yabluchanskiy A, Csipo T, Lipecz A, Tabak A, Institoris A, Csiszar A, Ungvari ZI. Obesityinduced cognitive impairment in older adults: a microvascular perspective. Am J Physiol Heart Circ Physiol. 2020;320(2):H740-61.

95. Yamamoto K, Takeshita K, Kojima T, Takamatsu J, Saito H. Aging and plasminogen activator inhibitor-1 (PAI-1) regulation: implication in the pathogenesis of thrombotic disorders in the elderly. Cardiovasc Res. 2005;66:276-85.

96. van Stralen KJ, Doggen CJ, Lumley T, Cushman M, Folsom AR, Psaty BM, Siscovick D, Rosendaal FR, Heckbert SR. The relationship between exercise and risk of venous thrombosis in elderly people. J Am Geriatr Soc. 2008;56:517-22.

97. Rosendaal FR, VANHV A, Doggen CJ. Venous thrombosis in the elderly. J Thromb Haemost. 2007;5(Suppl 1):310-7.

98. Engbers MJ, van Hylckama VA, Rosendaal FR. Venous thrombosis in the elderly: incidence, risk factors and risk groups. J Thromb Haemost. 2010;8:2105-12.

99. Vossen CY, Conard J, Fontcuberta J, Makris M, VDM FJ, Pabinger I, Palareti G, Preston FE, Scharrer I, Souto JC, Svensson P, Walker ID, Rosendaal FR. Risk of a first venous thrombotic event in carriers of a familial thrombophilic defect. The European Prospective Cohort on Thrombophilia (EPCOT). J Thromb Haemost. 2005;3:459-64.

100. Allaart CF, Poort SR, Rosendaal FR, Reitsma PH, Bertina RM, Briet E. Increased risk of venous thrombosis in carriers of hereditary protein $\mathrm{C}$ deficiency defect. Lancet. 1993;341:134-8.

101. van Boven HH, Vandenbroucke JP, Briet E, Rosendaal FR. Gene-gene and gene-environment interactions determine risk of thrombosis in families with inherited antithrombin deficiency. Blood. 1999;94:2590-4.

102. Bertina RM, Koeleman BP, Koster T, Rosendaal FR, Dirven RJ, de Ronde H, van der Velden PA, Reitsma PH. Mutation in blood coagulation factor $\mathrm{V}$ associated with resistance to activated protein C. Nature. 1994;369:64-7.

103. Rees DC, Cox M, Clegg JB. World distribution of factor V Leiden. Lancet. 1995;346:1133-4.

104. Svensson PJ, Dahlback B. Resistance to activated protein $\mathrm{C}$ as a basis for venous thrombosis. N Engl J Med. 1994;330:517-22.

105. Rosendaal FR, Doggen CJ, Zivelin A, Arruda VR, Aiach M, Siscovick DS, Hillarp A, Watzke HH, Bernardi F, Cumming AM, Preston FE, Reitsma PH. Geographic distribution of the $20210 \mathrm{G}$ to A prothrombin variant. Thromb Haemost. 1998;79:706-8.

106. Koster T, Rosendaal FR, de Ronde H, Briet E, Vandenbroucke JP, Bertina RM. Venous thrombosis due to poor anticoagulant response to activated protein C: Leiden Thrombophilia Study. Lancet. 1993;342:1503-6.

107. Tsai AW, Cushman M, Rosamond WD, Heckbert SR, Tracy RP, Aleksic N, Folsom AR. Coagulation factors, inflammation markers, and venous thromboembolism: the longitudinal investigation of thromboembolism etiology (LITE). Am J Med. 2002;113:636-42.

108. Folsom AR. Update on factor V Leiden association with venous thromboembolism in the LITE Study. Blood. 2007;109:1336-7.

109. Koster T, Blann AD, Briet E, Vandenbroucke JP, Rosendaal FR. Role of clotting factor VIII in effect of von Willebrand factor on occurrence of deep-vein thrombosis. Lancet. 1995;345:152-5.

110. van Hylckama VA, van der Linden IK, Bertina RM, Rosendaal FR. High levels of factor IX increase the risk of venous thrombosis. Blood. 2000;95:3678-82.

111. Meijers JC, Tekelenburg WL, Bouma BN, Bertina RM, Rosendaal FR. High levels of coagulation factor XI as a risk factor for venous thrombosis. $\mathrm{N}$ Engl $\mathrm{J}$ Med. 2000;342:696-701.

112. Bani-Hani M, Titi M, Al-Khaffaf H. Deep venous thrombosis after arterial surgery: a literature review. Eur J Vasc Endovasc Surg. 2008;36:565-73.

113. Ruskin KJ. Deep vein thrombosis and venous thromboembolism in trauma. Curr Opin Anaesthesiol. 2018;31:215-8.

114. Crous-Bou M, Harrington LB, Kabrhel C. Environmental and genetic risk factors associated with venous thromboembolism. Semin Thromb Hemost. 2016;42:808-20.

115. Leiva O, Newcomb R, Connors JM, Al-Samkari H. Cancer and thrombosis: new insights to an old problem. J Med Vasc. 2020;45:6S8-16.

116. Trousseau A. Lectures on clinical medicine, delivered at the Hotel-Dieu, Paris: London New Sydenham Society; 1868-1872(1).

117. Bikdeli B, Jimenez D, Hawkins M, Ortiz S, Prandoni P, Brenner B, Decousus H, Masoudi FA, Trujillo-Santos J, Krumholz HM, Monreal M, Investigators R. Rationale, design and methodology of the computerized registry of patients with venous thromboembolism (RIETE). Thromb Haemost. 2018;118:214-24. 
118. Kahn SR, Shrier I, Julian JA, Ducruet T, Arsenault L, Miron MJ, Roussin A, Desmarais S, Joyal F, Kassis J, Solymoss S, Desjardins L, Lamping DL, Johri M, Ginsberg JS. Determinants and time course of the postthrombotic syndrome after acute deep venous thrombosis. Ann Intern Med. 2008;149:698-707.

119. Bradbury AW. 2011 Pathophysiology and principles of management of varicose veins. In: R. Fitridge and M. Thompson, eds. Mechanisms of vascular disease: a reference book for vascular specialists Adelaide (AU)

120. Chandrashekar A, Garry J, Gasparis A, Labropoulos $\mathrm{N}$. Vein wall remodeling in patients with acute deep vein thrombosis and chronic postthrombotic changes. J Thromb Haemost. 2017;15:1989-93.

121. Du GC, Zhang MC, Zhao JC. Catheter-directed thrombolysis plus anticoagulation versus anticoagulation alone in the treatment of proximal deep vein thrombosis - a meta-analysis. Vasa. 2015;44:195-202.

122. Sharifi M, Freeman W, Bay C, Sharifi M, Schwartz F. Low incidence of post-thrombotic syndrome in patients treated with new oral anticoagulants and percutaneous endovenous intervention for lower extremity deep venous thrombosis. Vasc Med. 2015;20:112-6.

123. Sista AK, Vedantham S, Kaufman JA, Madoff DC. Endovascular interventions for acute and chronic lower extremity deep venous disease: state of the art. Radiology. 2015;276:31-53.

124. Semba CP, Dake MD. Iliofemoral deep venous thrombosis: aggressive therapy with catheter-directed thrombolysis. Radiology. 1994;191:487-94.

125. Comerota AJ. Current status of thrombolysis for acute deep venous thrombosis. Phlebolymphology. 2008;15:85-93.

126. Wang CN, Deng HR. Percutaneous endovenous intervention plus anticoagulation versus anticoagulation alone for treating patients with proximal deep vein thrombosis: a meta-analysis and systematic review. Ann Vasc Surg. 2018;49:39-48.

127. Labropoulos N, Summers KL, Sanchez IE, Raffetto J. Saphenous vein wall thickness in age and venous reflux-associated remodeling in adults. J Vasc Surg Venous Lymphat Disord. 2017;5:216-23.

128. Yang XP, Pei ZH, Ren J. Making up or breaking up: the tortuous role of platelet-derived growth factor in vascular ageing. Clin Exp Pharmacol Physiol. 2009;36:739-47.

129. Labropoulos N. How does chronic venous disease progress from the first symptoms to the advanced stages? A review Adv Ther. 2019;36:13-9.

130. Buján J, Pascual, G., Bellón JM. 2008 Interactions between ageing, inflammation process, and the occurence of varicose veins. phlebolymphology 123-130

131. Grudzińska E, Lekstan A, Szliszka E, Czuba ZP. Cytokines produced by lymphocytes in the incompetent great saphenous vein. Mediators Inflamm. 2018;2018:7161346.

132. Grudzińska E, Grzegorczyn S, Czuba ZP. Chemokines and growth factors produced by lymphocytes in the incompetent great saphenous vein. Mediators Inflamm. 2019;2019:7057303.
133. Beebe-Dimmer JL, Pfeifer JR, Engle JS, Schottenfeld D. The epidemiology of chronic venous insufficiency and varicose veins. Ann Epidemiol. 2005;15:175-84.

134. Kugler C, Strunk M, Rudofsky G. Venous pressure dynamics of the healthy human leg. Role of muscle activity, joint mobility and anthropometric factors. J Vasc Res. 2001;38:20-9.

135. Sachse C, Trozic I, Brix B, Roessler A, Goswami N. Sex differences in cardiovascular responses to orthostatic challenge in healthy older persons: a pilot study. Physiol Int. 2019;106:236-49.

136. Lee AJ, Robertson LA, Boghossian SM, Allan PL, Ruckley CV, Fowkes FG, Evans CJ. Progression of varicose veins and chronic venous insufficiency in the general population in the Edinburgh Vein Study. J Vasc Surg Venous Lymphat Disord. 2015;3:18-26.

137. Andreou ER, Koru-Sengul T, Linkins L, Bates SM, Ginsberg JS, Kearon C. Differences in clinical presentation of deep vein thrombosis in men and women. $\mathrm{J}$ Thromb Haemost. 2008;6:1713-9.

138. Bauersachs RM, Riess H, Hach-Wunderle V, Gerlach H, Carnarius H, Eberle S, Rabe E, Schellong SM. Impact of gender on the clinical presentation and diagnosis of deepvein thrombosis. Thromb Haemost. 2010;103:710-7.

139. Lussana F, Faioni EM, Mavilia C, Bucciarelli P, Brandi ML, Cattaneo M. Association of estrogen receptor-alpha genepolymorphisms with venous thrombosis. Haematologica. 2006;91:279-80.

140. Roach RE, Cannegieter SC, Lijfering WM. Differential risks in men and women for first and recurrent venous thrombosis: the role of genes and environment. J Thromb Haemost. 2014;12:1593-600.

141. Svartberg J, Braekkan SK, Laughlin GA, Hansen JB. Endogenous sex hormone levels in men are not associated with risk of venous thromboembolism: the Tromso study. Eur J Endocrinol. 2009;160:833-8.

142. Abou-Ismail MY, Citla Sridhar D, Nayak L. Estrogen and thrombosis: a bench to bedside review. Thromb Res. 2020;192:40-51.

143. Cushman M, Kuller LH, Prentice R, Rodabough RJ, Psaty BM, Stafford RS, Sidney S. Rosendaal FR and Women's Health Initiative I. Estrogen plus progestin and risk of venous thrombosis. JAMA. 2004;292:1573-80.

144. Post MS, Christella M, Thomassen LG, van der Mooren MJ, van Baal WM, Rosing J, Kenemans P, Stehouwer CD. Effect of oral and transdermal estrogen replacement therapy on hemostatic variables associated with venous thrombosis: a randomized, placebo-controlled study in postmenopausal women. Arterioscler Thromb Vasc Biol. 2003;23:1116-21.

145. Fulop GA, Tarantini S, Yabluchanskiy A, Molnar A, Prodan CI, Kiss T, Csipo T, Lipecz A, Balasubramanian P, Farkas E, Toth P, Sorond F, Csiszar A, Ungvari $\mathrm{Z}$. Role of age-related alterations of the cerebral venous circulation in the pathogenesis of vascular cognitive impairment. Am J Physiol Heart Circ Physiol. 2019;316:H1124-40.

146. Moody DM, Brown WR, Challa VR, Anderson RL. Periventricular venous collagenosis: association with leukoaraiosis. Radiology. 1995;194:469-76. 
147. Brown WR, Moody DM, Challa VR, Thore CR, Anstrom JA. Venous collagenosis and arteriolar tortuosity in leukoaraiosis. J Neurol Sci. 2002;203-204:159-63.

148. Keith J, Gao FQ, Noor R, Kiss A, Balasubramaniam G, $\mathrm{Au} \mathrm{K}$, Rogaeva E, Masellis M, Black SE. Collagenosis of the deep medullary veins: an underrecognized pathologic correlate of white matter hyperintensities and periventricular infarction? J Neuropathol Exp Neurol. 2017;76:299-312.

149. Xu Z, Li F, Wang B, Xing D, Pei Y, Yang B, Duan Y. New insights in addressing cerebral small vessel disease: association with the deep medullary veins. Front Aging Neurosci. 2020;12:597799.

150. Houck AL, Gutierrez J, Gao F, Igwe KC, Colon JM, Black SE, Brickman AM. Increased diameters of the internal cerebral veins and the basal veins of rosenthal are associated with white matter hyperintensity volume. AJNR Am J Neuroradiol. 2019;40:1712-8.

151. Jorgensen DR, Shaaban CE, Wiley CA, Gianaros PJ, Mettenburg J, Rosano C. A population neuroscience approach to the study of cerebral small vessel disease in midlife and late life: an invited review. Am J Physiol Heart Circ Physiol. 2018;314:H1117-36.

152. Shaaban CE, Aizenstein HJ, Jorgensen DR, MacCloud RL, Meckes NA, Erickson KI, Glynn NW, Mettenburg J, Guralnik J, Newman AB, Ibrahim TS, Laurienti PJ, Vallejo AN, Rosano C and Group LS. In vivo imaging of venous side cerebral small-vessel disease in older adults: an mri method at 7T. AJNR Am J Neuroradiol. 2017;38:1923-8.

153. WH Bouvy, HJ Kuijf, JJ Zwanenburg, HL Koek, LJ Kappelle, PR Luijten, MK Ikram, GJ Biessels and Utrecht Vascular Cognitive Impairment Study g. Abnormalities of cerebral deep medullary veins on 7 tesla MRI in amnestic mild cognitive impairment and early Alzheimer's disease: a pilot study. J Alzheimers Dis. 2017;57:705-10.

154. Lee AY, Han B, Lamm SD, Fierro CA, Han HC. Effects of elastin degradation and surrounding matrix support on artery stability. Am J Physiol Heart Circ Physiol. 2012;302:H873-84.

155. Hanif S, Abodunde O, Ali Z, Pidgeon C. Age related outcome in acute subdural haematoma following traumatic head injury. Ir Med J. 2009;102:255-7.

156. Yang AI, Balser DS, Mikheev A, Offen S, Huang JH, Babb J, Rusinek H, Samadani U. Cerebral atrophy is associated with development of chronic subdural haematoma. Brain Inj. 2012;26:1731-6.

157. Valecchi D, Bacci D, Gulisano M, Sgambati E, Sibilio M, Lipomas M, Macchi C. Internal jugular vein valves: an assessment of prevalence, morphology and competence by color Doppler echography in 240 healthy subjects. Ital J Anat Embryol. 2010;115:185-9.

158. Mayhan WG, Heistad DD. Role of veins and cerebral venous pressure in disruption of the blood-brain barrier. Circ Res. 1986;59:216-20.

159. Ungvari Z, Tarantini S, Kirkpatrick AC, Csiszar A, Prodan CI. Cerebral microhemorrhages: mechanisms, consequences, and prevention. Am J Physiol Heart Circ Physiol. 2017;312:H1128-43.
160. Chung CP, Lin YJ, Chao AC, Lin SJ, Chen YY, Wang YJ, Hu HH. Jugular venous hemodynamic changes with aging. Ultrasound Med Biol. 2010;36:1776-82.

161. Zivadinov R, Chung CP. Potential involvement of the extracranial venous system in central nervous system disorders and aging. BMC Med. 2013;11:260.

162. Uchino A, Nomiyama K, Takase Y, Nakazono T, Tominaga $\mathrm{Y}$, Imaizumi $\mathrm{T}$, Kudo $\mathrm{S}$. Retrograde flow in the dural sinuses detected by three-dimensional time-offlight MR angiography. Neuroradiology. 2007;49:211-5.

163. Inano S, Itoh D, Takao H, Hayashi N, Mori H, Kunimatsu A, Abe O, Aoki S, Ohtomo K. High signal intensity in the dural sinuses on 3D-TOF MR angiography at 3.0 T. Clin Imaging. 2010;34:332-6.

164. Kudo K, Terae S, Ishii A, Omatsu T, Asano T, Tha KK, Miyasaka K. Physiologic change in flow velocity and direction of dural venous sinuses with respiration: MR venography and flow analysis. AJNR Am J Neuroradiol. 2004;25:551-7.

165. Jang J, Kim BS, Kim BY, Choi HS, Jung SL, Ahn KJ, Byun JY. Reflux venous flow in dural sinus and internal jugular vein on 3D time-of-flight MR angiography. Neuroradiology. 2013;55:1205-11.

166. Kang Y, Kim E, Kim JH, Choi BS, Jung C, Bae YJ, Lee KM, Lee DH. Time of flight MR angiography assessment casts doubt on the association between transient global amnesia and intracranial jugular venous reflux. Eur Radiol. 2015;25:703-9.

167. Kim E, Kim JH, Choi BS, Jung C, Lee DH. MRI and MR angiography findings to differentiate jugular venous reflux from cavernous dural arteriovenous fistula. AJR Am J Roentgenol. 2014;202:839-46.

168. Beggs C, Chung CP, Bergsland N, Wang PN, Shepherd $\mathrm{S}$, Cheng CY, Dwyer MG, Hu HH, Zivadinov R. Jugular venous reflux and brain parenchyma volumes in elderly patients with mild cognitive impairment and Alzheimer's disease. BMC Neurol. 2013;13:157.

169. Belov P, Magnano C, Krawiecki J, Hagemeier J, Bergsland N, Beggs C, Zivadinov R. Age-related brain atrophy may be mitigated by internal jugular vein enlargement in male individuals without neurologic disease. Phlebology. 2017;32:125-34.

170. Albano B, Gandolfo C, Del Sette M. Post-coital intracerebral venous hemorrhage in a 78-year-old man with jugular valve incompetence: a case report. J Med Case Rep. 2010;4:225.

171. Guevarra AC, Ng SC, Saffari SE, Wong BYX, Chander $\mathrm{RJ}, \mathrm{Ng} \mathrm{KP}$, Kandiah N. Age moderates associations of hypertension, white matter hyperintensities, and cognition. J Alzheimers Dis. 2020;75:1351-60.

172. Freeze WM, Jacobs HIL, de Jong JJ, Verheggen ICM, Gronenschild E, Palm WM, Hoff EI, Wardlaw JM, Jansen JFA, Verhey FR, Backes WH. White matter hyperintensities mediate the association between bloodbrain barrier leakage and information processing speed. Neurobiol Aging. 2020;85:113-22.

173. Alber J, Alladi S, Bae HJ, Barton DA, Beckett LA, Bell JM, Berman SE, Biessels GJ, Black SE, Bos I, Bowman GL, Brai E, Brickman AM, Callahan BL, Corriveau RA, Fossati S, Gottesman RF, Gustafson DR, Hachinski V, Hayden KM, Helman AM, Hughes TM, Isaacs 
JD, Jefferson AL, Johnson SC, Kapasi A, Kern S, Kwon JC, Kukolja J, Lee A, Lockhart SN, Murray A, Osborn KE, Power MC, Price BR, Rhodius-Meester HFM, Rondeau JA, Rosen AC, Rosene DL, Schneider JA, Scholtzova H, Shaaban CE, Silva N, Snyder HM, Swardfager W, Troen AM, van Veluw SJ, Vemuri P, Wallin A, Wellington C, Wilcock DM, Xie SX, Hainsworth AH. White matter hyperintensities in vascular contributions to cognitive impairment and dementia (VCID): knowledge gaps and opportunities. Alzheimers Dement (N Y). 2019;5:107-17.

174. Uiterwijk R, van Oostenbrugge RJ, Huijts M, De Leeuw PW, Kroon AA, Staals J. Total cerebral small vessel disease MRI score is associated with cognitive decline in executive function in patients with hypertension. Front Aging Neurosci. 2016;8:301.

175. Altamura C, Scrascia F, Quattrocchi CC, Errante Y, Gangemi E, Curcio G, Ursini F, Silvestrini M, Maggio P, Beomonte Zobel B, Rossini PM, Pasqualetti P, Falsetti L, Vernieri F. Regional MRI diffusion, white-matter hyperintensities, and cognitive function in Alzheimer's disease and vascular dementia. J Clin Neurol. 2016;12:201-8.

176. Ble A, Ranzini M, Zurlo A, Menozzi L, Atti AR, Munari MR, Volpato S, Scaramelli G, Fellin R, Zuliani G. Leukoaraiosis is associated with functional impairment in older patients with Alzheimer's disease but not vascular dementia. J Nutr Health Aging. 2006;10:31-5.

177. O’Sullivan M. Leukoaraiosis. Pract Neurol. 2008;8:26-38.

178. Makedonov I, Black SE, MacIntosh BJ. Cerebral small vessel disease in aging and Alzheimer's disease: a comparative study using MRI and SPECT. Eur J Neurol. 2013;20:243-50.

179. Kandel BM, Avants BB, Gee JC, McMillan CT, Erus G, Doshi J, Davatzikos C, Wolk DA. White matter hyperintensities are more highly associated with preclinical Alzheimer's disease than imaging and cognitive markers of neurodegeneration. Alzheimers Dement (Amst). 2016;4:18-27.

180. Jacobs HI, Clerx L, Gronenschild EH, Aalten P, Verhey FR. White matter hyperintensities are positively associated with cortical thickness in Alzheimer's disease. J Alzheimers Dis. 2014;39:409-22.

181. Mortamais M, Artero S, Ritchie K. White matter hyperintensities as early and independent predictors of Alzheimer's disease risk. J Alzheimers Dis. 2014;42(Suppl 4):S393-400.

182. Kapadia A, Dmytriw AA. Venous dysfunction plays a critical role in "normal" white matter disease of aging. Med Hypotheses. 2021;146:110457.

183. Chung CP, Hu HH. Pathogenesis of leukoaraiosis: role of jugular venous reflux. Med Hypotheses. 2010;75:85-90.

184. Wu R, Feng C, Zhao Y, Jin AP, Fang M, Liu X. A meta-analysis of association between cerebral microbleeds and cognitive impairment. Med Sci Monit. 2014;20:2189-98.

185. Chai C, Wang Z, Fan L, Zhang M, Chu Z, Zuo C, Liu L, Mark Haacke E, Guo W, Shen W, Xia S. Increased number and distribution of cerebral microbleeds is a risk factor for cognitive dysfunction in hemodialysis patients: a longitudinal study. Medicine (Baltimore). 2016;95:e2974.

186. van Norden AG, van den Berg HA, de Laat KF, Gons RA, van Dijk EJ, de Leeuw FE. Frontal and temporal microbleeds are related to cognitive function: the Radboud University Nijmegen Diffusion Tensor and Magnetic Resonance Cohort (RUN DMC) Study. Stroke. 2011;42:3382-6.

187. Hilal S, Saini M, Tan CS, Catindig JA, Koay WI, Niessen WJ, Vrooman HA, Wong TY, Chen C, Ikram MK, Venketasubramanian N. Cerebral microbleeds and cognition: the epidemiology of dementia in Singapore study. Alzheimer Dis Assoc Disord. 2014;28:106-12.

188. Poels MM, Ikram MA, van der Lugt A, Hofman A, Niessen WJ, Krestin GP, Breteler MM, Vernooij MW. Cerebral microbleeds are associated with worse cognitive function: the Rotterdam Scan Study. Neurology. 2012;78:326-33.

189. Werring DJ, Frazer DW, Coward LJ, Losseff NA, Watt H, Cipolotti L, Brown MM, Jager HR. Cognitive dysfunction in patients with cerebral microbleeds on T2*weighted gradient-echo MRI. Brain. 2004;127:2265-75.

190. Werring DJ, Gregoire SM, Cipolotti L. Cerebral microbleeds and vascular cognitive impairment. J Neurol Sci. 2010;299:131-5.

191. Yakushiji Y, Noguchi T, Charidimou A, Eriguchi M, Nishihara M, Hara M, Nanri Y, Horikawa E, Nishiyama M, Werring DJ, Hara H. Basal ganglia cerebral microbleeds and global cognitive function: the Kashima Scan Study. J Stroke Cerebrovasc Dis. 2015;24:431-9.

192. Yakushiji Y, Werring DJ. Cerebrovascular disease: lobar cerebral microbleeds signal early cognitive impairment. Nat Rev Neurol. 2016;12:680-2.

193. Sumbria RK, Grigoryan MM, Vasilevko V, Krasieva TB, Scadeng M, Dvornikova AK, Paganini-Hill A, Kim R, Cribbs DH, Fisher MJ. A murine model of inflammationinduced cerebral microbleeds. J Neuroinflammation. 2016;13:218.

194. Fulop GA, Ahire C, Csipo T, Tarantini S, Kiss T, Balasubramanian P, Yabluchanskiy A, Farkas E, Toth A, NyulToth A, Toth P, Csiszar A, Ungvari Z. Cerebral venous congestion promotes blood-brain barrier disruption and neuroinflammation, impairing cognitive function in mice. Geroscience. 2019;41:575-89.

195. Rotta J, Perosa V, Yakupov R, Kuijf HJ, Schreiber F, Dobisch L, Oltmer J, Assmann A, Speck O, Heinze HJ. Acosta-Cabronero J, Duzel E and Schreiber S. Detection of cerebral microbleeds with venous connection at 7 tesla MRI. Neurology. 2021;16:e2048-57.

196. Ungvari Z, Yabluchanskiy A, Tarantini S, Toth P, Kirkpatrick AC, Csiszar A, Prodan CI. Repeated Valsalva maneuvers promote symptomatic manifestations of cerebral microhemorrhages: implications for the pathogenesis of vascular cognitive impairment in older adults. Geroscience. 2018;40(5-6):485-96.

197. Sharpey-Schafer EP. The mechanism of syncope after coughing. Br Med J. 1953;2:860-3.

198. Wysoki MG, Covey A, Pollak J, Rosenblatt M, Aruny J, Denbow N. Evaluation of various maneuvers for prevention of air embolism during central venous catheter placement. J Vasc Interv Radiol. 2001;12:764-6. 
199. Chung CP, Beggs C, Wang PN, Bergsland N, Shepherd $\mathrm{S}$, Cheng CY, Ramasamy DP, Dwyer MG, Hu HH, Zivadinov R. Jugular venous reflux and white matter abnormalities in Alzheimer's disease: a pilot study. J Alzheimers Dis. 2014;39:601-9.

200. Zivadinov R. Is there a link between the extracranial venous system and central nervous system pathology? BMC Med. 2013;11:259.

201. Fisher J, Vaghaiwalla F, Tsitlik J, Levin H, Brinker J, Weisfeldt M, Yin F. Determinants and clinical significance of jugular venous valve competence. Circulation. 1982;65:188-96.

202. Biffi A, Greenberg SM. Cerebral amyloid angiopathy: a systematic review. J Clin Neurol. 2011;7:1-9.

203 Morrone CD, Bishay J, McLaurin J. 2020 Potential role of venular amyloid in Alzheimer's disease pathogenesis. Int J Mol Sci. 1985;21:6.

204. Favaloro RG. Saphenous vein graft in the surgical treatment of coronary artery disease. Operative technique J Thorac Cardiovasc Surg. 1969;58:178-85.

205. Alexander JH, Hafley G, Harrington RA, Peterson ED, Ferguson TB Jr, Lorenz TJ, Goyal A, Gibson M, Mack MJ, Gennevois D, Califf RM, Kouchoukos NT. Efficacy and safety of edifoligide, an E2F transcription factor decoy, for prevention of vein graft failure following coronary artery bypass graft surgery: PREVENT IV: a randomized controlled trial. JAMA. 2005;294:2446-54.

206. Klein B, Destephens A, Dumeny L, Hu Q, He Y, O’Malley K, Jiang Z, Tran-Son-Tay R, Berceli S. Hemodynamic influence on smooth muscle cell kinetics and phenotype during early vein graft adaptation. Ann Biomed Eng. 2017;45:644-55.

207. Owens CD, Gasper WJ, Rahman AS, Conte MS. Vein graft failure. J Vasc Surg. 2015;61:203-16.

208. MS Conte, DF Bandyk, AW Clowes, GL Moneta, L Seely, TJ Lorenz, H Namini, AD Hamdan, SP Roddy, M Belkin, SA Berceli, RJ DeMasi, RH Samson, SS Berman and Investigators PI. Results of PREVENT III: a multicenter, randomized trial of edifoligide for the prevention of vein graft failure in lower extremity bypass surgery. J Vasc Surg. 2006;43:742-51 (discussion 751).

209. Mohan R, Walter PJ, Vandermast M, Amsel BJ, Vanaken D. Isolated coronary artery bypass grafting in patients 75 years of age and older: is age per se a contraindication? Thorac Cardiovasc Surg. 1992;40:365-70.

210. Khan SS, Kupfer JM, Matloff JM, Tsai TP, Nessim S. Interaction of age and preoperative risk factors in predicting operative mortality for coronary bypass surgery. Circulation. 1992;86(Ii186):90.

211. Lau H, Cheng SW. Long-term prognosis of femoropopliteal bypass: an analysis of 349 consecutive revascularizations. ANZ J Surg. 2001;71:335-40.

212. Kondo Y, Muto A, Kudo FA, Model L, Eghbalieh S, Chowdhary P, Dardik A. Age-related Notch-4 quiescence is associated with altered wall remodeling during vein graft adaptation. J Surg Res. 2011;171:e149-60.

213. Kudo FA, Muto A, Maloney SP, Pimiento JM, Bergaya S, Fitzgerald TN, Westvik TS, Frattini JC, Breuer CK, Cha CH, Nishibe T, Tellides G, Sessa WC, Dardik A. Venous identity is lost but arterial identity is not gained during vein graft adaptation. Arterioscler Thromb Vasc Biol. 2007;27:1562-71.

214. van der Loo B, Labugger R, Skepper JN, Bachschmid M, Kilo J, Powell JM, Palacios-Callender M, Erusalimsky JD, Quaschning T, Malinski T, Gygi D, Ullrich V, Lüscher TF. Enhanced peroxynitrite formation is associated with vascular aging. J Exp Med. 2000;192:1731-44.

215. Adler A, Messina E, Sherman B, Wang Z, Huang H, Linke A, Hintze TH. NAD(P)H oxidase-generated superoxide anion accounts for reduced control of myocardial $\mathrm{O} 2$ consumption by NO in old Fischer 344 rats. Am J Physiol Heart Circ Physiol. 2003;285:H1015-22.

216. Jacobson A, Yan C, Gao Q, Rincon-Skinner T, Rivera A, Edwards J, Huang A, Kaley G, Sun D. Aging enhances pressure-induced arterial superoxide formation. Am J Physiol Heart Circ Physiol. 2007;293:H1344-50.

217. Csiszar A, Sosnowska D, Wang M, Lakatta EG, Sonntag WE, Ungvari Z. Age-associated proinflammatory secretory phenotype in vascular smooth muscle cells from the non-human primate Macaca mulatta: reversal by resveratrol treatment. J Gerontol A Biol Sci Med Sci. 2012;67:811-20.

218. Sun D, Huang A, Yan EH, Wu Z, Yan C, Kaminski PM, Oury TD, Wolin MS, Kaley G. Reduced release of nitric oxide to shear stress in mesenteric arteries of aged rats. Am J Physiol Heart Circ Physiol. 2004;286:H2249-56.

219. Hamilton CA, Brosnan MJ, McIntyre M, Graham D, Dominiczak AF. Superoxide excess in hypertension and aging: a common cause of endothelial dysfunction. Hypertension. 2001;37:529-34.

220 Francia P, delli Gatti C, Bachschmid M, Martin-Padura I, Savoia C, Migliaccio E, Pelicci PG, Schiavoni M, Luscher TF, Volpe M, Cosentino F. Deletion of p66shc gene protects against age-related endothelial dysfunction. Circulation. 2004;110:2889-95.

221. Csiszar A, Labinskyy N, Orosz Z, Xiangmin Z, Buffenstein R, Ungvari Z. Vascular aging in the longest-living rodent, the naked mole-rat. Am J Physiol. 2007;293:H919-27.

222. Ungvari ZI, Orosz Z, Labinskyy N, Rivera A, Xiangmin Z, Smith KE, Csiszar A. Increased mitochondrial $\mathrm{H} 2 \mathrm{O} 2$ production promotes endothelial NF-kB activation in aged rat arteries. Am J Physiol Heart Circ Physiol. 2007;293:H37-47.

223. Jablonski KL, Seals DR, Eskurza I, Monahan KD, Donato AJ. High-dose ascorbic acid infusion abolishes chronic vasoconstriction and restores resting leg blood flow in healthy older men. J Appl Physiol. 2007;103:1715-21.

224. Kiss T, Nyul-Toth A, Balasubramanian P, Tarantini S, Ahire C, DelFavero J, Yabluchanskiy A, Csipo T, Farkas E, Wiley G, Garman L, Csiszar A, Ungvari Z. Single-cell RNA sequencing identifies senescent cerebromicrovascular endothelial cells in the aged mouse brain. Geroscience. 2020;42(2):429-44.

225. Regina C, Panatta E, Candi E, Melino G, Amelio I, Balistreri CR, Annicchiarico-Petruzzelli M, Di Daniele N, Ruvolo G. Vascular ageing and endothelial cell senescence: molecular mechanisms of physiology and diseases. Mech Ageing Dev. 2016;159:14-21. 
226. Rossman MJ, Kaplon RE, Hill SD, McNamara MN, Santos-Parker JR, Pierce GL, Seals DR, Donato AJ. Endothelial cell senescence with aging in healthy humans: prevention by habitual exercise and relation to vascular endothelial function. Am J Physiol Heart Circ Physiol. 2017;313:H890-5.

227. Csiszar A, Wang M, Lakatta EG, Ungvari ZI. Inflammation and endothelial dysfunction during aging: role of NF-\{kappa\}B. J Appl Physiol. 2008;105(4):1333-41.

228. Eskandari A, Soori R, Choobineh S, Mazaheri TZ. Exercise promotes heart regeneration in aged rats by increasing regenerative factors in myocardial tissue. Physiol Int. 2020;107:166-76.

229. Sagi B, Peti A, Lakatos O, Gyimesi T, Sulyok E, Wittmann I and Csiky B. 2020 Pro- and anti-inflammatory factors, vascular stiffness and outcomes in chronic hemodialysis patients. Physiol Int

230. Kovacs E, Pilecky D, Szakal-Toth Z, Fekete-Gyor A, Gyarmathy VA, Geller L, Hauser B, Gal J, Merkely B and Zima E. 2020 The role of age in post-cardiac arrest therapy in an elderly patient population. Physiol Int

231. Sumida K, Kovesdy CP. The gut-kidney-heart axis in chronic kidney disease. Physiol Int. 2019;106:195-206.

232. Donato AJ, Black AD, Jablonski KL, Gano LB, Seals DR. Aging is associated with greater nuclear NF kappa $\mathrm{B}$, reduced I kappa B alpha, and increased expression of proinflammatory cytokines in vascular endothelial cells of healthy humans. Aging Cell. 2008;7:805-12.

233. Ungvari Z, Kaley G, de Cabo R, Sonntag WE, Csiszar A. Mechanisms of vascular aging: new perspectives. J Gerontol A Biol Sci Med Sci. 2010;65:1028-41.

234. Csiszar A, Labinskyy N, Smith K, Rivera A, Orosz Z, Ungvari Z. Vasculoprotective effects of anti-TNFalfa treatment in aging. Am J Pathol. 2007;170:388-698.

235. Pearson KJ, Baur JA, Lewis KN, Peshkin L, Price NL, Labinskyy N, Swindell WR, Kamara D, Minor RK, Perez E, Jamieson HA, Zhang Y, Dunn SR, Sharma K, Pleshko N, Woollett LA, Csiszar A, Ikeno Y, Le Couteur D, Elliott PJ, Becker KG, Navas P, Ingram DK, Wolf NS, Ungvari Z, Sinclair DA, de Cabo R. Resveratrol delays age-related deterioration and mimics transcriptional aspects of dietary restriction without extending life span. Cell Metab. 2008;8:157-68.

236. Asai K, Kudej RK, Shen YT, Yang GP, Takagi G, Kudej AB, Geng YJ, Sato N, Nazareno JB, Vatner DE, Natividad F, Bishop SP, Vatner SF. Peripheral vascular endothelial dysfunction and apoptosis in old monkeys. Arterioscler Thromb Vasc Biol. 2000;20:1493-9.

237. Kun L, Ying L, Lei W, Jianhua Z, Yongbo X, Tao W, Jinyuan T, Haibo C. Dysregulated apoptosis of the venous wall in chronic venous disease and portal hypertension. Phlebology. 2016;31:729-36.

238. Mitchell SJ, Martin-Montalvo A, Mercken EM, Palacios HH, Ward TM, Abulwerdi G, Minor RK, Vlasuk GP, Ellis JL, Sinclair DA, Dawson J, Allison DB, Zhang Y, Becker KG, Bernier M, de Cabo R. The SIRT1 activator SRT1720 extends lifespan and improves health of mice fed a standard diet. Cell Rep. 2014;6:836-43.

239. Miranda MX, van Tits LJ, Lohmann C, Arsiwala T, Winnik S, Tailleux A, Stein S, Gomes AP, Suri V, Ellis JL, Lutz TA, Hottiger MO, Sinclair DA, Auwerx
J, Schoonjans K, Staels B, Luscher TF, Matter CM. The Sirt1 activator SRT3025 provides atheroprotection in Apoe-/- mice by reducing hepatic Pcsk9 secretion and enhancing Ldlr expression. Eur Heart J. 2014;36(1):51-9.

240. Price NL, Gomes AP, Ling AJ, Duarte FV, MartinMontalvo A, North BJ, Agarwal B, Ye L, Ramadori G, Teodoro JS, Hubbard BP, Varela AT, Davis JG, Varamini B, Hafner A, Moaddel R, Rolo AP, Coppari R, Palmeira CM, de Cabo R, Baur JA, Sinclair DA. SIRT1 is required for AMPK activation and the beneficial effects of resveratrol on mitochondrial function. Cell Metab. 2012;15:675-90.

241. Bonkowski MS, Sinclair DA. Slowing ageing by design: the rise of $\mathrm{NAD}(+)$ and sirtuin-activating compounds. Nat Rev Mol Cell Biol. 2016;17:679-90.

242. Csiszar A, Labinskyy N, Jimenez R, Pinto JT, Ballabh P, Losonczy G, Pearson KJ, de Cabo R, Ungvari Z. Antioxidative and anti-inflammatory vasoprotective effects of caloric restriction in aging: role of circulating factors and SIRT1. Mech Ageing Dev. 2009;130:518-27.

243. Csiszar A, Labinskyy N, Pinto JT, Ballabh P, Zhang H, Losonczy G, Pearson KJ, de Cabo R, Pacher P, Zhang C, Ungvari ZI. Resveratrol induces mitochondrial biogenesis in endothelial cells. Am J Physiol Heart Circ Physiol. 2009;297(1):H13-20.

244. Ungvari Z, Labinskyy N, Mukhopadhyay P, Pinto JT, Bagi Z, Ballabh P, Zhang C, Pacher P, Csiszar A. Resveratrol attenuates mitochondrial oxidative stress in coronary arterial endothelial cells. Am J Physiol Heart Circ Physiol. 2009;297:H1876-81.

245. Lee IH, Cao L, Mostoslavsky R, Lombard DB, Liu J, Bruns NE, Tsokos M, Alt FW, Finkel T. A role for the NAD-dependent deacetylase Sirt1 in the regulation of autophagy. Proc Natl Acad Sci U S A. 2008;105:3374-9.

246. Gomes AP, Price NL, Ling AJ, Moslehi JJ, Montgomery MK, Rajman L, White JP, Teodoro JS, Wrann CD, Hubbard BP, Mercken EM, Palmeira CM, de Cabo R, Rolo AP, Turner N, Bell EL, Sinclair DA. Declining $\mathrm{NAD}(+)$ induces a pseudohypoxic state disrupting nuclear-mitochondrial communication during aging. Cell. 2013;155:1624-38.

247. Massudi H, Grant R, Braidy N, Guest J, Farnsworth B, Guillemin GJ. Age-associated changes in oxidative stress and NAD+ metabolism in human tissue. PLoS ONE. 2012;7:e42357.

248. Csiszar A, Wang M, Lakatta EG, Ungvari ZI. Inflammation and endothelial dysfunction during aging: role of NF-\{kappa\}B. J Appl Physiol. 2008;105:1333-41.

249. Yao XL, Liu H, Li P, Chen WP, Guan SX, Chen Y, Wu YN, Lin BQ. Aqueous extract of Whitmania Pigra Whitman alleviates thrombus burden via Sirtuin $1 / \mathrm{NF}-\kappa \mathrm{B}$ pathway. J Surg Res. 2020;245:441-52.

250. Lu H, Sun L, Chen W, Zhou Y, Liu K, Chen J, Zhang Z, Zhang C, Tian H. Sirtuin 3 therapy attenuates aging expression, oxidative stress parameters, and neointimal hyperplasia formation in vein grafts. Ann Vasc Surg. 2020;64:303-17.

251. Ungvari Z, Bailey-Downs L, Gautam T, Sosnowska D, Wang M, Monticone RE, Telljohann R, Pinto JT, de Cabo R, Sonntag WE, Lakatta E, Csiszar A. Age-associated 
vascular oxidative stress, Nrf2 dysfunction and NF-kB activation in the non-human primate Macaca mulatta. $\mathbf{J}$ Gerontol A Biol Sci Med Sci. 2011;66:866-75.

252. Ungvari Z, Bailey-Downs L, Sosnowska D, Gautam T, Koncz P, Losonczy G, Ballabh P, de Cabo R, Sonntag WE, Csiszar A. Vascular oxidative stress in aging: a homeostatic failure due to dysregulation of Nrf2-mediated antioxidant response. Am J Physiol Heart Circ Physiol. 2011;301:H363-72.

253. Ungvari ZI, Bailey-Downs L, Gautam T, Jimenez R, Losonczy G, Zhang C, Ballabh P, Recchia FA, Wilkerson DC, Sonntag WE, Pearson KJ, de Cabo R, Csiszar A. Adaptive induction of NF-E2-related factor-2-driven antioxidant genes in endothelial cells in response to hyperglycemia. Am J Physiol Heart Circ Physiol. 2011;300:H1133-40.

254. Suh JH, Shenvi SV, Dixon BM, Liu H, Jaiswal AK, Liu RM, Hagen TM. Decline in transcriptional activity of Nrf2 causes age-related loss of glutathione synthesis, which is reversible with lipoic acid. Proc Natl Acad Sci U S A. 2004;101:3381-6.

255. Feng J, Luo J, Deng L, Zhong Y, Wen X, Cai Y, Li J. Naringenin-induced HO-1 ameliorates high glucose or free fatty acids-associated apoptosis via PI3K and JNK/ Nrf2 pathways in human umbilical vein endothelial cells. Int Immunopharmacol. 2019;75:105769.

256. Chapple SJ, Keeley TP, Mastronicola D, Arno M, Vizcay-Barrena G, Fleck R, Siow RCM, Mann GE. Bach1 differentially regulates distinct Nrf2-dependent genes in human venous and coronary artery endothelial cells adapted to physiological oxygen levels. Free Radic Biol Med. 2016;92:152-62.

257. Chen CC, Hong HJ, Hao WR, Cheng TH, Liu JC, Sung LC. Nicorandil prevents doxorubicin-induced human umbilical vein endothelial cell apoptosis. Eur J Pharmacol. 2019;859:172542.

258. Zhou X, Liang L, Zhao Y, Zhang H. Epigallocatechin3-gallate ameliorates angiotensin ii-induced oxidative stress and apoptosis in human umbilical vein endothelial cells through the activation of Nrf2/caspase-3 signaling. J Vasc Res. 2017;54:299-308.

259. Tang C, Tan S, Zhang Y, Dong L, Xu Y. Activation of Keap1-Nrf2 signaling by 4-octyl itaconate protects human umbilical vein endothelial cells from high glucose. Biochem Biophys Res Commun. 2019;508:921-7.

260. Mostoslavsky R, Chua KF, Lombard DB, Pang WW, Fischer MR, Gellon L, Liu P, Mostoslavsky G, Franco S, Murphy MM, Mills KD, Patel P, Hsu JT, Hong AL, Ford E, Cheng HL, Kennedy C, Nunez N, Bronson R, Frendewey D, Auerbach W, Valenzuela D, Karow M, Hottiger MO, Hursting S, Barrett JC, Guarente L, Mulligan R, Demple B, Yancopoulos GD, Alt FW. Genomic instability and aging-like phenotype in the absence of mammalian SIRT6. Cell. 2006;124:315-29.

261. Fulop GA, Kiss T, Tarantini S, Balasubramanian P, Yabluchanskiy A, Farkas E, Bari F, Ungvari Z, Csiszar A. Nrf2 deficiency in aged mice exacerbates cellular senescence promoting cerebrovascular inflammation. Geroscience. 2018;40:513-21.

262. Tarantini S, Valcarcel-Ares MN, Yabluchanskiy A, Tucsek Z, Hertelendy P, Kiss T, Gautam T, Zhang XA,
Sonntag WE, de Cabo R, Farkas E, Elliott ME, Kinter MT, Deak F, Ungvari Z, Csiszar A. Nrf2 deficiency exacerbates obesity-induced oxidative stress, neurovascular dysfunction, blood brain barrier disruption, neuroinflammation, amyloidogenic gene expression and cognitive decline in mice, mimicking the aging phenotype. J Gerontol A Biol Sci Med Sci. 2018;73(7):853-63.

263. Akin-Bali DF, Eroglu T, Ilk S, Egin Y, Kankilic T. Evaluation of the role of Nrf2/Keap1 pathway-associated novel mutations and gene expression on antioxidant status in patients with deep vein thrombosis. Exp Ther Med. 2020;20:868-81.

264. Johnson SC, Sangesland M, Kaeberlein M, Rabinovitch PS. Modulating mTOR in aging and health. Interdiscip Top Gerontol. 2015;40:107-27.

265. Caccamo A, Majumder S, Richardson A, Strong $\mathrm{R}$, Oddo S. Molecular interplay between mammalian target of rapamycin (mTOR), amyloid-beta, and Tau: effects on cognitive impairments. J Biol Chem. 2010;285:13107-20.

266. Lin AL, Zheng W, Halloran JJ, Burbank RR, Hussong SA, Hart MJ, Javors M, Shih YY, Muir E, Solano Fonseca R, Strong R, Richardson AG, Lechleiter JD, Fox PT, Galvan V. Chronic rapamycin restores brain vascular integrity and function through NO synthase activation and improves memory in symptomatic mice modeling Alzheimer's disease. J Cereb Blood Flow Metab. 2013;33:1412-21.

267. Wang CY, Kim HH, Hiroi Y, Sawada N, Salomone S, Benjamin LE, Walsh K, Moskowitz MA, Liao JK. Obesity increases vascular senescence and susceptibility to ischemic injury through chronic activation of Akt and mTOR. Science signaling. 2009;6(2):ra11.

268. Yepuri G, Velagapudi S, Xiong Y, Rajapakse AG, Montani JP, Ming XF, Yang Z. Positive crosstalk between arginase-II and S6K1 in vascular endothelial inflammation and aging. Aging Cell. 2012;11:1005-16.

269. Parlar A, Can C, Erol A, Ulker S. Posttransplantation therapeutic rapamycin concentration protects nitric oxide-related vascular endothelial function: comparative effects in rat thoracic aorta and coronary endothelial cell culture. Transpl Proc. 2010;42:1923-30.

270. Cheng C, Tempel D, Oostlander A, Helderman F, Gijsen F, Wentzel J, van Haperen R, Haitsma DB, Serruys PW, van der Steen AF, de Crom R, Krams R. Rapamycin modulates the eNOS vs. shear stress relationship. Cardiovasc Res. 2008;78:123-9.

271. Corbin F, Blaise GA, Parent M, Chen H, Daloze PM. Effect of rapamycin on rat aortic ring vasomotion. J Cardiovasc Pharmacol. 1994;24:813-7.

272. Milliard S, Silva A, Blaise G, Chen H, Xu D, Qi S, Daloze P. Rapamycin's effect on vasomotion in the rat. Transpl Proc. 1998;30:1036-8.

273. Lesniewski LA, Seals DR, Walker AE, Henson GD, Blimline MW, Trott DW, Bosshardt GC, LaRocca TJ, Lawson BR, Zigler MC, Donato AJ. Dietary rapamycin supplementation reverses age-related vascular dysfunction and oxidative stress, while modulating nutrient-sensing, cell cycle, and senescence pathways. Aging Cell. 2017;16:17-26. 
274. Ortega MA, Asunsolo A, Leal J, Romero B, AlvarezRocha MJ, Sainz F, Alvarez-Mon M, Bujan J, GarciaHonduvilla N. Implication of the PI3K/Akt/mTOR pathway in the process of incompetent valves in patients with chronic venous insufficiency and the relationship with aging. Oxid Med Cell Longev. 2018;2018:1495170.

275. Wang W, Li Y, Wang Q, Cao Y, Wang F, Li W. Identification and analysis of differentially expressed genes in human saphenous vein endothelial cells overexpressing domain-containing mTOR-interacting protein (DEPTOR) by RNA-Seq. Med Sci Monit. 2019;25:6965-71.

276. Allman-Farinelli MA, Dawson B. Diet and aging: bearing on thrombosis and hemostasis. Semin Thromb Hemost. 2005;31:111-7.

277. Rabe E, Pannier F. Clinical, aetiological, anatomical and pathological classification (CEAP): gold standard and limits. Phlebology. 2012;27(Suppl 1):114-8.

278. Wang M, Zhang L, Zhu W, Zhang J, Kim SH, Wang Y, Ni L, Telljohann R, Monticone RE, McGraw K, Liu L, de Cabo R, Lakatta EG. Calorie restriction curbs proinflammation that accompanies arterial aging, preserving a youthful phenotype. J Am Heart Assoc. 2018;7:e009112.
279. Roos CM, Zhang B, Palmer AK, Ogrodnik MB, Pirtskhalava T, Thalji NM, Hagler M, Jurk D, Smith LA, Casaclang-Verzosa G, Zhu Y, Schafer MJ, Tchkonia T, Kirkland JL, Miller JD. Chronic senolytic treatment alleviates established vasomotor dysfunction in aged or atherosclerotic mice. Aging Cell. 2016;15:973-7.

280. Tarantini S, Valcarcel-Ares NM, Yabluchanskiy A, Fulop GA, Hertelendy P, Gautam T, Farkas E, Perz A, Rabinovitch PS, Sonntag WE, Csiszar A, Ungvari Z. Treatment with the mitochondrial-targeted antioxidant peptide SS-31 rescues neurovascular coupling responses and cerebrovascular endothelial function and improves cognition in aged mice. Aging Cell. 2018;17(2):e12731.

Publisher's note Springer Nature remains neutral with regard to jurisdictional claims in published maps and institutional affiliations. 